\title{
From Mesenchymal Stromal/Stem Cells to Insulin-Producing Cells: Progress and Challenges
}

\author{
Mohamed A. Ghoneim ${ }^{1}$ (D) $\cdot$ Ayman F. Refaie ${ }^{1} \cdot$ Batoul L. Elbassiouny ${ }^{1} \cdot$ Mahmoud M. Gabr $^{1} \cdot$ Mahmoud M. Zakaria $^{1}$
}

Published online: 3 September 2020

(C) The Author(s) 2020

\begin{abstract}
Mesenchymal stromal cells (MSCs) are an attractive option for cell therapy for type 1 diabetes mellitus (DM). These cells can be obtained from many sources, but bone marrow and adipose tissue are the most studied. MSCs have distinct advantages since they are nonteratogenic, nonimmunogenic and have immunomodulatory functions. Insulin-producing cells (IPCs) can be generated from MSCs by gene transfection, gene editing or directed differentiation. For directed differentiation, MSCs are usually cultured in a glucose-rich medium with various growth and activation factors. The resulting IPCs can control chemically-induced diabetes in immune-deficient mice. These findings are comparable to those obtained from pluripotent cells. $\mathrm{PD}-\mathrm{L}_{1}$ and $\mathrm{PD}-\mathrm{L}_{2}$ expression by MSCs is upregulated under inflammatory conditions. Immunomodulation occurs due to the interaction between these ligands and PD-1 receptors on $\mathrm{T}$ lymphocytes. If this function is maintained after differentiation, life-long immunosuppression or encapsulation could be avoided. In the clinical setting, two sites can be used for transplantation of IPCs: the subcutaneous tissue and the omentum. A 2-stage procedure is required for the former and a laparoscopic procedure for the latter. For either site, cells should be transplanted within a scaffold, preferably one from fibrin. Several questions remain unanswered. Will the transplanted cells be affected by the antibodies involved in the pathogenesis of type $1 \mathrm{DM}$ ? What is the functional longevity of these cells following their transplantation? These issues have to be addressed before clinical translation is attempted.
\end{abstract}

Keywords MSCs $\cdot$ differentiation $\cdot$ IPCs $\cdot$ transplantation $\cdot$ encapsulation $\cdot$ scaffolds $\cdot$ immunomodulation $\cdot$ diabetes

\section{Introduction}

Diabetes mellitus (DM) is a major health concern. In 2014, more than 400 million people suffered from DM globally compared to 108 million in 1980. If this trend continues, the number is expected to increase to more than 600 million by 2045 [1]. Type 1 DM (T1DM) accounts for $\approx 5 \%$ of all diabetic patients and is the result of destruction of pancreatic islets through an autoimmune-mediated response. Patients depend on exogenous insulin injections throughout their life. However, this treatment does not prevent acute or chronic complications. Glycemic control without a need for exogenous insulin can be achieved by $\beta$-cell replacement through transplantation of the whole pancreas or its islets. Despite the increasing success of both approaches, their applications are

Mohamed A. Ghoneim

ghoneimma@yahoo.com

1 Urology and Nephrology Center, Mansoura, Egypt limited by organ availability and the need for life-long immunosuppression.

Recent progress in the field of regenerative therapies provides an alternative means through the generation of surrogate $\beta$-cells from various stem cell sources. Soria and associates reported successful production of insulin-secreting cells derived from embryonic stem cells (ESCs) by gene transfection of a human insulin gene in mice [2]. Lumelsky et al. reported successful differentiation of mouse ESCs using a five-step protocol [3]. The Lumelsky protocol was then modified by Segev et al. by adding a suspension culture step at the end of the differentiation scheme [4]. These early reports were challenged by Rajagopal and colleagues, who argued that the presence of insulin in the cells is due to its sequestration from the culture media and not from intrinsic synthesis [5]. In a landmark study, Kubo and associates reported the development of definitive endoderm from ESCs in culture using activin A [6]. This finding was successfully reproduced one year later by D'Amour et al. [7]. On this basis, protocols for directed differentiation of human ESCs (hESCs) towards pancreatic endocrine lineage were developed $[8,9]$. These cells were believed to undergo further maturation following their 
transplantation under the influence of the in vivo milieu. Rezania and colleagues developed a 7-step protocol that converts hESCs into insulin-producing cells (IPCs) that could reverse diabetes in mice 40 days after transplantation [10]. A multistep differentiation protocol for hESCs or human induced pluripotent stem cells (hiPSCs) was developed by Pagliuca et al. [11]. The aim of this study was to generate glucose-responsive mature $\beta$-cells at the end of in vitro differentiation. However, the use of human pluripotent stem cells to generate IPCs has 2 major drawbacks: immunogenicity and teratogenicity. These 2 issues dictate the need for encapsulation of these cells within an immunoisolation device for transplantation in a clinical setting.

A viable alternative can be provided by mesenchymal stem/stromal cells (MSCs). These cells are widely available in many tissues, and can be readily expanded in vitro with a doubling time of 48-72 hours [12]. Many studies have reported that MSCs can differentiate into mesodermal and nonmesodermal lineages [13]. In most animal studies and clinical trials, MSCs were reported safe and well tolerated. Compared to ESCs and iPSCs, human MSCs (hMSCs) were found to impose a negligible teratogenic risk. However, their possible role in the spread and metastasis of pre-existing cancer was noted [14]. MSCs also lack the expression of HLA class II antigens and have a possible immunomodulatory function. These characteristics may, therefore, allow their application in an allogenic setting. Thus, MSCs have become a promising therapeutic agent in regenerative medicine and are the subject of intensive research [15]. An appraisal of the use of MSCs to produce IPCs is timely and is the subject matter of this review. Studies on islet transplantation or pluripotent stem cellderived $\beta$ cells are frequently quoted to note their shortcomings and exploit any advantages.

\section{Mesenchymal Stem/Stromal Cells}

\section{Nomenclature}

Previous studies by Friedenstein et al. revealed that cells from bone marrow stroma could generate bone, fat and cartilage cells following heterotopic transplantation [16]. These results suggested the existence of non-haematopoietic bone marrow precursor cells with skeletal and adipogenic potential. For these cells, the term stromal cells was first suggested by Owen [17]. The term mesenchymal stem cells was then popularized by Caplan to refer to plastic-adhering cell preparations isolated from various tissues [18]. More recently, leading investigators of mesenchymal cell therapy have provided convincing data showing that the "stemness" of these cells is lacking [19]. Since these cells are found within the supportive stroma of their resident tissues, the term mesenchymal stromal cell was introduced, which allows the abbreviation "MSCs" to be unchanged. Given the multipotent differentiation capacity of these cells, they have been finally named multipotent mesenchymal stromal cells by the International Society for Cellular Therapy [20]. The term mesenchymal was maintained to indicate the origin and not the differentiation capacity of these cells.

\section{Characteristics}

The defining features of MSCs are inconsistent. Many laboratories have developed methods to isolate and expand MSCs, which can result in subtle differences. To address this issue, the Mesenchymal and Tissue Stem Cell Committee proposed a set of standards to define human MSCs [21]. First, MSCs must be plastic adherent when maintained in standard culture flasks. Additionally, $\geq 95 \%$ of the MSCs must express CD105, $\mathrm{CD} 73$, and CD90 and lack expression $(\leq 2 \%)$ of CD45, CD34, CD14 and HLA class II antigens as shown by flow cytometry. Finally, these cells must be able to differentiate into osteoblasts, adipocytes and chondroblasts under standard in vitro differentiating regimens. These characteristic features are subject to changes as a result of several variables, such as culture conditions, tissue of origin, number of population doublings and passage density [22]. Hence, additional markers, including stro-1, CD271, SSEA-4, and CD146, were suggested for more specific identification [23]. MSCs can also express HLA-DR class II antigens under stimulatory conditions, such as with interferon . Furthermore, after 22 population doublings, these cells were reported to lose their adipogenic potential [24]. These factors must be considered when MSCs are used as such or after their differentiation towards a specific lineage.

\section{Variations on a Theme}

Different culture conditions for MSCs have important implications for the final cell population, as they may selectively support the expansion of a certain subpopulation [22]. Reyes and associates described a culture system for MSCs that favors the selection of a subpopulation of primitive cells referred to as multipotent adult progenitor cells or MAPCs [25]. Later, these authors had to retract their publication due to lack of reproducibility and contradictory findings by other investigators [26]. Kogler et al. described a pluripotent CD45(-) cell population from human cord blood [27]. This population shows adherent growth and can be expanded without losing pluripotency. These cells were termed unrestricted somatic stem cells or USSCs. D'Ippolito et al. reported the isolation of a population of pluripotent human cells from bone marrow after their expansion in media similar to that in the in vivo microenvironment of the most primitive cells. These cells were called marrow-isolated adult multilineage inducible or MIAMI cells [28]. Kucia et al. identified a population of 
CXCR4(+), very small embryonic-like stem cells (VSELs) in murine bone marrow and human cord blood [29]. A population of CD105(+) and SEEAA-3(+) cells was isolated from bone marrow stromal cells by Kuroda and coworkers. This population was defined as multilineage stress enduring (Muse) cells [30].

On a different note, the relationship between MSCs and pericytes (Rouget cells) is unclear. Studies have shown that MSCs are localized next to blood vessels [31]. Pericytes also have a perivascular location and display a marker profile and multipotent differentiation potential similar to MSCs [32]. Thus, distinguishing between the two cell types is difficult. Two alternative explanations were proposed: either pericytes are MSCs with a perivascular location or pericytes represent a distinct subpopulation of MSCs [33]. Pericytes are identified by surface marker expression of NG2 and CD146. In culture, CD146(+) MSCs form endothelial tube-like structures, while CD146(-) cells do not. However, CD146(-) MSCs were shown to acquire a CD146(+) phenotype in culture [34]. On this basis, MSCs can only be distinguished from pericytes by their lack of angiogenic function [32].

MSCs are a heterogeneous population of multipotent stromal cells. Attempts to isolate different subpopulations are work intensive and could be confusing. In this review, the specific features identified by the International Society for Cellular Therapy will be used.

\section{Sources}

For differentiation into IPCs, MSCs were derived from both perinatal and adult tissues. Perinatal sources include the amniotic fluid [35], Wharton's jelly [36], umbilical cord stroma [37, 38], umbilical cord blood [39] and placenta [40]. Adult sources include bone marrow [41-46], adipose tissue [47-49], dental pulp [50, 51], tonsils [52], endometrium [53], periosteum [54], peripheral blood [55], and liver cells [56]. Among these sources, bone marrow and adipose tissue are the most studied. While obtaining a sample from the bone marrow is a painful invasive procedure, liposuction aspiration is frequently practiced, and their plentiful yield should not be wasted. The volume of human marrow retrieved under local anaesthesia does not exceed $\approx 40 \mathrm{ml}$. In contrast, a harvest from adipose tissue under local anaesthesia is $\approx 200 \mathrm{ml}$. According to Strem et al., $1 \mathrm{ml}$ of adipose tissue aspirate yields $\approx 5000$ adipose tissue mesenchymal stem cells (AT-MSCs). A similar volume of bone marrow aspirate yields approximately 600-1000 bone marrow mesenchymal stem cells (BM-MSCs) [57]. These data indicate a clear advantage of adipose tissue as a source of MSCs. One possible application for bone marrow is the use of BM-MSCs in autologous protocols. Similarly, stored umbilical cord-derived MSCs can serve as an excellent autologous source for their donors in case of a future need. Recently, there is an increasing interest in the use of Wharton's jelly-derived
MSCs to generate IPCs [58, 59]. It provides an unlimited source for MSCs without ethical considerations. One million MSCs can be collected from a $20-\mathrm{cm}$ umbilical cord. In addition, the derived MSCs have a high replication capacity without observed senescence up-to 80 population doublings [60].

\section{Isolation, Expansion and Verification}

Isolation of MSCs from tissue samples relies on their adherence to the plastic material of the culture plates. Before sampling, prospective donors must be screened for communicable disease. In addition, a biochemical and hematological profile is obtained with special emphasis on a coagulation profile. The methods of isolation and expansion of MSCs from bone marrow or liposuction aspirates were described in detail by Gabr et al. [61]. Modified protocols for isolation and expansion were devised to enhance the yield, and hence, clinical applicability was also reported $[62,63]$. The purity of isolated and expanded MSCs must be tested according to the criteria specified by the International Society for Cellular Therapy [21].

\section{From MSCs to IPCs}

In general, IPCs could be derived from MSCs by one of two approaches: gene manipulation or directed differentiation. For analysis of successful production of surrogate $\beta$-cells, seven criteria were suggested by Calne and Ghoneim [64] and are as follows: 1. Presence of insulin storage granules in the surrogate $\beta$-cells. 2. Co-expression of $\mathrm{C}$-peptide and insulin in the same cells. 3. Release of insulin and C-peptide in response to a glucose challenge. 4. Control of hyperglycemia following transplantation. 5. Weight gain and a responsive glucose tolerance curve of the transplanted animals. 6. Prompt return of diabetes when the surrogate $\beta$-cells are removed. 7 . No regeneration of islets observed among the chemically induced diabetes in animals or regeneration of pancreas in the pancreatectomized animals.

\section{Gene Manipulation}

This procedure can be implemented by either gene transfection using a viral vector or by genetic engineering.

\section{Genetic Transfection}

Gene transfection can be carried out either by in vitro gene delivery into cells, which are then transplanted into a recipient, or by direct delivery of genes in vivo. Chen and associates transfected liver cells in vitro with a plasmid harboring the human insulin gene [65]. The resulting cells were injected back as an autologous graft in the liver of diabetic pigs. 
According to these authors, insulin production and improvement of hyperglycemia were observed for more than 9 months. Direct infusion of a lentiviral vector encoding a human gene into the portal system of rats with streptozotocin (STZ)-induced diabetes was reported by Ren et al. [66]. The blood glucose of the treated animals was normalized for 500 days. Karnieli et al. transfected human bone marrow MSCs with rat $P d x 1$ using a BABE-hygromycin vector [67]. Although glucose-stimulated insulin secretion was demonstrated in vitro, the cells lacked Neurodl expression. Transplantation of these cells in mice with STZ-induced diabetes resulted in their further differentiation with expression of Neurod1 and a reduction of hyperglycemia. Qing-Song and coworkers transfected MSCs from murine bone marrow with 3 transcription factors, $P d x 1$, Neurodl and Mafa, using an adenoviral vector [68]. The transfected cells were then transplanted into the liver parenchyma of mice with chemically induced diabetes. Seven days after transplantation, the treated animals demonstrated glucose tolerance curves similar to the normal controls. However, this result was not sustained after 14 days, presumably due to unstable or transient gene expression. Boroujeni and Aleyasin transfected human ATMSCs (hAT-MSCs) with PDX1 using a lentivirus vector [69]. The transfected cells were then cultured in highglucose DMEM supplemented with B27, nicotinamide and fibroblast growth factor. The expression of $P D X-1, N G N 3$ and GLUT2 was detected by RT-PCR. Four million cells were intraperitoneally transplanted into Sprague-Dawley rats with alloxan-induced diabetes. The authors reported that hyperglycemia was normalized within 3-4 days and maintained for several months, which was astonishing since it followed a xenogeneic transplantation without immunoisolation or immunosuppression. Thi Do and associates transfected porcine bone marrow-derived MSCs with the insulin gene using a lentiviral vector [70]. Autologous transplantation of the treated cells in the liver of pigs with STZ-induced diabetes resulted in partial improvement of their hyperglycemia. The generation of IPCs from hBM-MSCs by transfection with both miR-375 and anti-miR-9 was reported by Jafarian and associates [71]. The authors suggested that while miR-375 is responsible for insulin gene expression and secretion, miR-9 inhibits insulin exocytosis. Bai et al. generated IPCs from nestin-positive umbilical cord MSCs of chickens by transfection with miR-375 and miR-26a [72]. These cells were then transplanted under the renal capsules of SCID mice with chemically induced diabetes. Two weeks after transplantation, chicken insulin was detected in the sera of glucose-challenged mice.

Although MSCs were not involved in their experiments, a brief account of the experimental findings of Fatima Bosch and her group from Barcelona is worth mentioning. In 2006, this group reported successful treatment of mice with STZinduced diabetes by intramuscular injection of an adenoassociated vector (AAV) encoding the genes for insulin and glucokinase [73]. Insulin production in addition to glucose phosphorylation were necessary to achieve normoglycemia. In 2013, this group published the results of treatment of chemically induced diabetes in 4 dogs using the same principle: intramuscular injection of an AAV vector encoding the insulin and glucokinase genes [74]. Normalization of fasting glucose and accelerated normoglycemia after a glucose challenge without episodes of hypoglycemia were noted. This benefit was maintained for 4 years. In a follow-up study, the authors reported that normoglycemia in 2 of the treated dogs was sustained for 8 years [75]. We question why an approach with such excellent results was not translated to the clinic or whether these observations were the result of regeneration of the native pancreata.

\section{Gene Editing}

The use of viral vectors has major limitations due to possible oncogene transactivation and the lack of physiological expression that allows monitoring. Recently, gene therapy researchers have focused on gene editing technologies as an alternative approach [76]. The breakthrough in genome editing started in 2013, when the first CRISPR/Cas9 system was engineered to work in mammalian cells [77, 78]. The endonuclease activity of Cas 9 can be inactivated, forming nuclease-deficient Cas9 (dCas9). Transcriptional activators can be fused to dCas9. Subsequently, this combination can be guided by a target-specific RNA (sgRNA) to the upstream promotor region of an endogenous gene, leading to the upregulation of its expression [79]. If a single sgRNA is used, activation of a given gene is negligible. Multiplexing with 3 or more sgRNAs leads to synergistic activation with a significant increase in gene expression [80]. Gimenez et al. successfully induced endogenous human insulin transcription using the dCas9-VP160 transcriptional activator and multiple insulin promoter targeting RNAs in human embryonic kidney cells and human fibroblasts [81]. The CRISPR/Cas9 gene editing system was also used to identify the role of several transcription factors involved in pancreatic embryonic development [82]. These investigators generated mutant lines affecting 8 transcription factors. Six of these genes (PDX1, RFX6, PTFIA, GLIS3, MNX1 and NGN3) were found to be associated with permanent neonatal diabetes mellitus (PNDM). Mutations in a subset of these genes (PDXI and PTF1A) are associated with several deficiencies in endocrine and exocrine functions (pancreatic agenesis). Induced pluripotent stem cells were generated from skin fibroblasts of a patient with PNDM followed by their differentiation into the pancreatic endocrine lineage. The resulting cells did not contain or secrete insulin. Genetic editing of these cells using the CRISPR/Cas9 system was carried out. A guide RNA against the insulin locus close to the mutation site was designed along with a correction template. Genetically corrected cells showed $\approx 53 \%$ insulin- 
positive cells [83]. Collectively, the field of genetic engineering is rapidly evolving. We should investigate further developments and refinements that may lead to possible clinical applications.

\section{Directed Differentiation}

Several authors have reported that under certain culture conditions, MSCs can form cells that do not belong to a mesodermal lineage [84-86]. This phenomenon can reflect transdifferentiation or differentiation of a pluripotent subgroup of a heterogeneous population [15]. In 2004, 3 groups of investigators reported successful differentiation of murine bone marrow-derived MSCs into IPCs [87-89]. These early observations were reproduced by Timper and her group using hATMSCs [47]. Sun and associates could differentiate hBMMSCs from diabetic patients to form IPCs [41]. These early observations were followed by multiple reports using either BM-MSCs or AT-MSCs [43, 45, 48, 90-92]. To this end, various protocols were employed. In general, cells were cultured in glucose-rich media with different growth and activation factors. In our laboratory, hBM-MSCs were obtained from diabetic as well as healthy volunteers, and a 3-step differentiation protocol was used [42]. Initially, mercaptoethanol was used to induce $P D X 1$ expression in the cells. Subsequently, nonessential amino acids, basic fibroblast growth factor, epidermal growth factor and B27 supplement were added. Finally, activin A and nicotinamide were supplemented. At the end of differentiation, $\approx 5 \%$ of the cells tested positive for insulin and C-peptide. This modest yield did not vary between cells obtained from diabetic or healthy individuals. Electron microscopy with nanogold immunolabelling revealed C-peptide granules at the rough endoplasmic reticulum. A stepwise increase in the release of insulin and Cpeptide in response to increasing glucose concentrations was also noted. Moreover, the differentiated cells expressed all the relevant pancreatic endocrine genes. Transplantation of these cells under the renal capsule of nude mice with STZ-induced diabetes resulted in the control of their diabetes within 7-10 days. The sera of the treated animals contained human insulin and C-peptide, with negligible levels of mouse insulin. When the cell-bearing kidney was removed, diabetes rapidly returned. In other words, the 7 criteria were satisfied in this experimental trial [64]. In another study, the yield of IPCs from hBM-MSCs and hAT-MSCs was compared. The results were essentially the same without a significant difference [61]. The relative efficiency of 3 differentiation protocols was also evaluated [93]. The yield of functional IPCs was modest and comparable among the 3 methods. Given its simplicity and the short duration required for its completion, trichostatin-A (TSA)/glucagon-like peptide-1 (GLP-1), introduced by Tayaramma [94], became our method of choice. Despite these modest results, we demonstrated that after transplantation, the proportion of differentiated cells increased to reach $\approx 18 \%$, presumably due to favorable in vivo factors [95]. Efforts to improve the yield of IPCs using various strategies, including differentiation in a suspension culture [44], on a scaffold [96] or within an extracellular matrix, were reported [97]. Choi et al. [98] and Xie et al. [99] observed that an extract from an injured pancreas could promote the differentiation of rat MSCs into IPCs. In a proteomic study, 3 proteins were differentially expressed from injured pancreata of Sprague-Dawley rats: cofilin1, nucleoside diphosphate kinase (NDPKA) and peroxiredoxin-6 (PRDX6) [100]. The yield of IPCs when these proteins were added to the differentiation medium alone or in combination was evaluated [101]. The best outcome was observed in samples supplemented with PRDX6 alone, where the yield of IPCs increased by 4 -fold compared to that of the controls.

The results of cell therapy for experimental type $1 \mathrm{DM}$ from 3 leading groups were compiled by Schulz [10]. Table 1 is a summary of these data. The results of MSCderived IPCs from 2 studies were also added for comparison $[42,45]$. The data shows that the efficiency of MSCs as a source for IPCs is as good as, if not better than, pluripotent stem cells.

\section{Selection of a Site for Cell Transplantation}

The sites for cell transplantation were summarized by several thorough reviews based on studies of islet transplantation [102-105]. A number of factors can influence the choice of a suitable site: an animal experiment or a clinical application? A small animal or a large one? Autologous cells or allogenic cells? Transplantation of free cells, cells on a scaffold or cells in an encapsulation device? For animal experiments, cells were grafted under the skin [106], in striated muscles [107], within the epidydimal fat pad [9], under the renal capsules [42] or inside an omental pouch [108], among several other sites. For a clinical application, choices are more restricted. When IPCs derived from MSCs are considered, two sites provide a distinct advantage: under the skin or within an omental pouch. The subcutaneous sites are easily accessible, and a minimally invasive procedure can be used. The main disadvantage of these sites is the poor blood supply. To overcome this problem, Pepper et al. suggested a 2 -stage procedure [106]. In the first stage, plastic tubes were inserted under the skin to induce the formation of new blood vessels. Cell transplantation into this pre-vascularized bed was then carried out in a second stage. In contrast, the omentum has a rich vascular supply in which capillaries form numerous spiral loops. This capillary bed lies directly under a very thin layer of mesothelium. Thus, early oxygenation for the transplanted cells is guaranteed with free exchange of glucose, insulin and metabolites. Furthermore, omental venous blood drains into the 
Table 1 Comparison of experimental cell therapies for type $1 \mathrm{DM}$

\begin{tabular}{|c|c|c|c|c|c|}
\hline Variable & Keiffer (10) & Melton (11) & $\begin{array}{l}\text { Kroon (8) } \\
\text { Schulz (9) }\end{array}$ & Ghoneim (42) & Xin (45) \\
\hline Source of Cells & ESCs & ESCs, iPSCs & ESCs & MSCs & MSCs \\
\hline Cellular Product & $\beta$ cells & $\beta$ cells & $\begin{array}{l}\text { Pancreatic progenitor } \\
\text { cells }\end{array}$ & IPCs & IPCs \\
\hline Differentiation Scheme & 7 steps & 6 steps & 4 steps & 3 steps & 3 steps \\
\hline Length of Differentiation (days) & $27-42$ & $27-35$ & 12 & 22 & 29 \\
\hline Implant Dose & $1.25 \times 10^{6}$ & $5 \times 10^{6}$ & $3 \times 10^{6}$ & $3 \times 10^{6}$ & $3 \times 10^{6}$ \\
\hline Site of Implant & Kidney capsule & Kidney capsule & Subcutaneous & Kidney capsule & Kidney capsule \\
\hline Time to Correct Hyperglycaemia in Mice (days) & $\approx 50-60$ & $\approx 75$ & $\approx 50-70$ & $\approx 7-10$ & 6 \\
\hline Clinical Trial & ---- & ----- & Yes (Phase I/II) & ----- & ----- \\
\hline
\end{tabular}

portal system. As early as 1983, Yasunami and associates reported experimental islet transplantation in a peritonealomental pouch [108]. Evidence for the superiority of the omentum over other sites for cell engraftment and function was later documented in 2 experimental studies [109, 110]. The feasibility of creating an omental pouch suitable for clinical application was explored by Berman et al. [111]. Diabetes was chemically induced in rats as well as non-human primates. Islets were implanted onto the omentum within a plasma-thrombin biological scaffold. The study concluded that the feasibility and efficiency of this protocol justified proceeding to a pilot phase I/II clinical trial. To our knowledge, the first clinical trial was published as a case report by Baidal and colleagues [112]. This trial is a part of an ongoing study entitled "Allogenic islet cells transplanted onto the omentum" (ClinicalTrials. gov. Identifier: NCT 02213003). A 43-year-old female patient with a 25-year history of type I DM was controlled by exogenous insulin. Allogenic islets were transplanted laparoscopically on the omentum in a fibrin scaffold generated from autologous plasma and recombinant thrombin. The patient received induction followed by maintenance immunosuppression. Insulin was discontinued 17 days after transplantation. With continuous glucose monitoring, the 7-day mean glucose level was $\approx 109 \mathrm{mg} / \mathrm{dL}$, and the glycated haemoglobin was 6 . $0 \%$. The patient exercised regularly and followed a lowcarbohydrate diet, which probably contributed to her stable glycemic control. At 12 months, a functional decline was noted. The authors speculate that this finding might be due to a switch from tacrolimus to sirolimus for maintenance immunosuppression. Nevertheless, the patient continued to have stable control without exogenous insulin or hypoglycemic episodes. These encouraging results will pave the way for many clinical trials using different sources of IPCs. If IPCs derived from MSCs are used, immunosuppression may not be necessary, avoiding its possible undesirable side effects.

\section{Platforms for Cell Transplantation}

IPCs, generated from various sources, can be engrafted as free cells. This procedure is usually performed under certain experimental conditions, such as transplantation under the renal capsules of immune deficient mice. Alternatively, cells may be encapsulated within an immunoisolation device or on a scaffold material.

Immunoisolation is necessary to protect the graft from allogenic responses and/or autoantibodies. This condition is usually achieved by cell encapsulation within a biocompatible semipermeable membrane. Cell transplantation in encapsulation devices has several challenges and should meet certain requirements. The permeability of such a membrane should allow the free exchange of oxygen and nutrients with good insulin kinetics in response to changes in blood glucose levels. Moreover, the membrane should block high molecular weight complexes, cytokines and immune cells. Early oxygenation of the enclosed cells must be ensured, and the host responses in the form of a foreign body tissue reaction should be minimized to prevent pericapsular fibrosis. Immunoisolation devices are classified according to their size into microencapsulation or macroencapsulation.

\section{Microencapsulation}

Lim and Sun were the first to report microencapsulation for islet transplantation [113]. Since then, a growing number of studies in rodents, pigs, dogs and non-human primates have been conducted, employing a wide range of materials [114]. Typically, cells are incorporated in an alginate hydrogel covered with a semipermeable membrane (usually poly-L-lysine or ornithine) to provide appropriate permeability and mechanical strength. While these capsules can support islet function in small animals, they were inefficient in those with strong immune systems, including large animals, non-human primates and humans [115]. In 1994, Soon-Shiong et al. reported the first clinical trial of microencapsulated intraperitoneal islet 
transplantation in a type I diabetic patient. These investigators reported early insulin independence [116]. However, the patient had to receive exogenous insulin followed by a second transplant to maintain glycaemic control for 58 months.

Recently, several attempts to improve the functional longevity of microencapsulation were reported. Dang and associates showed that alginates mixed with curcumin inhibit foreign body reactions when transplanted under the skin [117]. Hybrid alginate microcapsules incorporating curcumin were used to encapsulate pancreatic islets derived from SpragueDawley rats. When transplanted in mice with STZ-induced diabetes, they could provide better control of blood sugar than that of the controls for 2 months. The microencapsulation device was optimized by conformal coatings [118]. The aim was to conform the coating of the microcapsules according to the shape and size of the encapsulated cells. A coating with a uniform thickness was obtained, in contrast to conventional methods in which capsules of a similar diameter are engineered independent of the size of enclosed cells. Veiseh and associates studied the influence of the size of the microcapsules on the intensity of the foreign body tissue reaction and/or the induction of an immune response [119]. They concluded that larger alginate spheres in the range of $1.5 \mathrm{~mm}$ reduced fibrosis and minimized immune cell deposition. They also reported that when rat islet cells encapsulated in $1.5 \mathrm{~mm}$ alginate capsules were transplanted in mice with STZ-induced diabetes, blood glucose levels were controlled 5 times longer than that with conventionally sized $0.5 \mathrm{~mm}$ capsules. Materials that mitigate foreign body reactions in primates were studied by Vegas et al. [120]. These researchers identified 3 triazole analogues that substantially reduced the foreign body tissue reaction, recognition by macrophages and fibrosis. In a subsequent study, the same group reported that triazole-thiomorpholine dioxide (TMTD) alginate capsules incorporating mature $\beta$-cells derived from hESCs provided long-term glycemic control without immunosuppression when transplanted in immune-competent mice [121].

\section{Macroencapsulation}

These are further classified into either intravascular or extravascular devices. Intravascular macroencapsulation involves loading of the engrafted cells within hollow semipermeable tubes that are directly connected to the recipient vasculature. The transplanted cells are in direct contact with the bloodstream and receive an adequate supply of oxygen and nutrients. However, this method is associated with several limiting complications, such as clot formation and embolization [122]. Extravascular macroencapsulation can be engineered in a tubular or a planar configuration. Tubular devices are weak and susceptible to rupture, whereas planar devices are more stable. In addition, planar devices can be retrieved at predetermined time points for examination of their content. This flat design allows a suitable cell seeding density relative to the surface area. Nevertheless, macroencapsulation devices face a number of important challenges. The enclosed cells have to be near a blood supply at a distance not exceeding 150-200 $\mu \mathrm{m}$ to allow diffusion of oxygen and nutrients. Cells located away from an adequate blood supply are subject to necrosis and death. Furthermore, since no direct vascular access is present, the diffusion time for oxygen, glucose and insulin is prolonged. Thus, the production of insulin and its release are delayed. Accumulation of insulin within the capsule puts the enclosed graft at risk of insulin inhibition from their own product [123]. Data from clinical islet transplantation indicate that $\approx 5000$ islet equivalents per $\mathrm{kg}$ body weight (IEQ/ $\mathrm{kg}$ ) is required for the control of diabetes. For a $70-\mathrm{kg}$ person, $\approx 350,000$ IEQ will be required. The surface area to volume ratio must be optimized to minimize the diffusion distances between the host vasculature and the encapsulated cells. It is suggested that a surface area of $\approx 460 \mathrm{~cm}^{2}$ is needed if 350,000 IEQ are to be encapsulated [124]. To overcome the problem of cell hypoxia, researchers used several approaches. A 2-stage procedure was reported, where subcutaneous implantation of an empty device was initially performed to induce vascularization. In the second stage, cells were loaded into the prevascularized encapsulation device $[125,126]$. Alternatively, a biological oxygen donor may be used to support in situ oxygen requirements and prevent hypoxia-induced cell damage $[127,128]$. Another group of investigations found that the incorporation of vasculogenic agents enhances the survival and function of encapsulated cells [129-131]. An interesting new material, HEMOXCell, is an extracellular haemoglobin extracted from a marine invertebrate (Hemarina, Morlaix, France). This substance is nonimmunogenic and can bind to 156 oxygen molecules (human haemoglobin can bind a maximum of 4), and oxygen is delivered on demand. When added to MSCs in vitro cultures, HEMOXCell increased the cell proliferation rate and preserved their viability [132]. The efficiency of HEMOXCell and perfluorodecalin as biological carriers was compared. Both agents were added to in vitro cultures of islets derived from Wistar rats. Under hypoxic conditions, the use of HEMOXCell maintained islet viability and restored its function, while perfluorodecalin did not [133].

The TheraCyte capsule is a bilayer planar device that was used in several experimental studies (Irvine, CA, USA). This device consists of an outer layer of polytetrafluoroethylene (PTFE) with $5 \mu \mathrm{m}$ sized pores. The inner layer is made from the same material with a pore size of $0.45 \mu \mathrm{m}$ to provide immunoisolation. A polyester mesh is attached to the outer layer to induce vascularization. In several studies, this device was shown to provide immunoisolation in allogenic and xenogeneic settings. Variable degrees of control of diabetes were also reported [133-137]. In a preliminary study, Gabr et al. differentiated hBM-MSCs to form IPCs. The differentiated cells were loaded into TheraCyte capsules and transplanted 
into dogs with chemically induced diabetes at a dose of $5 \times 10^{6}$ cells $/ \mathrm{kg}$. Four of 6 dogs became euglycemic for a period of 6 months. Thereafter, there was a gradual and progressive rise in blood glucose levels [138]. Histology of the explanted capsules revealed a significant amount of pericapsular fibrosis. In another study, pancreatic progenitor cells derived from $\mathrm{hESCs}$ were transplanted in the epididymal fat pads or under the skin within a TheraCyte capsule in athymic nude rats [139]. The authors reported that human C-peptide and insulin were detected at very low levels without an increase following a glucose challenge. These results indicate that the extent of endocrine cell formation or secretory function does not qualify for clinical application.

A modified TheraCyte capsule, Encaptra, was developed by Viacyte (Viacyte Inc., San Diego, CA). The device was loaded with pancreatic progenitor cells derived from hESCs [8]. Evidence has shown that transplantation of this combination can control chemically induced diabetes in rodents [9, 140]. On behalf of Viacyte, the results of the first clinical trial using this system for islet replacement in type I diabetic patients were presented by D'Amour, in the 2018's International Pancreas and Islet Transplantation Association meeting, and reported by Odorico et al. [141]. The study included 19 patients in an open-label trial. A high degree of patient variability was observed. The 12-week explants showed minimal cell survival with cell death likely due to hypoxia. The trial was paused to improve their immunoisolation device. In a second attempt, their cells are to be encapsulated in an open system. Thus, anti-inflammatory agents as well as standard immune suppression have to be administered.

In another study, Pepper and associates developed what is known as the Sernova pouch (Sernova Corp., London, Ontario, Canada). This device is macroporous and was not intended to be immunoisolating. The empty device was inserted under the skin of BALB/c mice to provoke neovascularization. Four weeks later, chemically induced diabetes was induced, and syngeneic islets were transplanted into the pouch. To serve as a control, another group of animals was transplanted with islets under the renal capsule. Diabetic control was comparable between the groups [142]. The authors concluded that this device is biocompatible and provides a suitable environment for islet transplantation. However, a 3year phase I/II clinical study using this device was terminated after recruiting 3 patients [143]. This finding strongly shows that translation from experimental findings to a clinical trial is not always successful.

Ludwig and associates developed a macroencapsulation device under the commercial name $\beta$-Air. This device consists of 3 compartments layered in a disc-shaped capsule. The outer 2 compartments house the transplanted tissue, while the middle compartment serves as an oxygen reservoir that can be refilled from an external oxygen delivery system via an access port. A pilot clinical study was carried out in which the $\beta$-Air device containing 2100 IEQ $/ \mathrm{kg}$ was transplanted preperitoneally in a 63-year-old male patient with a long history of treatment for type $1 \mathrm{DM}$. During a follow-up period of 10 months, persistently low $\mathrm{HbA} 1 \mathrm{c}$ with a reduction in insulin requirements was observed [144]. Despite this modest result, a clinical trial with human islets was initiated (ClinicalTrials. gov.Identifier:NCT02064309). Nevertheless, Korsgren reported that the kinetics of insulin release from $\beta$ Air are far from ideal [145]. Maximal insulin secretion following a glucose challenge occurred after $\approx 4$ hours. In contrast, maximal insulin secretion from non-encapsulated (native) islets occurs within a few minutes. Carlsson and associates reported their clinical experience with the $\beta$-Air device in a phase 1 study [146]. Four patients were transplanted with this device into which $1800-4600 \mathrm{IEQ} / \mathrm{kg}$ islets were loaded. Patients were followed up for 3-6 months. At the end of the observation period, the implanted devices were retrieved. Improvements in $\mathrm{HbAlc}$ were noted in 3 of the 4 patients. However, this improvement was not significant. The insulin requirements were not reduced. Histology of the retrieved capsules demonstrated pericapsular deposition of fibrous tissue. The authors concluded that the device can support the survival of allogenic islets for several months, although the function of the transplanted cells was limited. In our opinion, this conclusion is unsatisfactory, and the reported results do not justify further clinical studies.

It is abundantly clear that the available encapsulation devices require further optimization and refinement. Induction of the foreign body reaction and subsequent fibrosis must be minimized. Adequate vascularization to avoid cell hypoxia must be ensured. Since encapsulation relies on passive diffusion of oxygen, glucose, insulin and metabolites, high blood glucose levels must be reached before insulin is released. Reduction of the distance between the enclosed cells, as much as possible, is also required to minimize the delay in insulin release.

\section{Scaffolds}

Scaffolds are in effect an open system that allows free permeation of oxygen and nutrients. These devices can also allow a $3 \mathrm{D}$ arrangement of the loaded cells, a distinct advantage for cell differentiation or transplantation [147-150].

Scaffolds can be engineered from synthetic or natural materials. The different materials utilized for their construction, as well as the advantages and limitations of each, were the subject of extensive reviews [151-153]. Mitrousis and associates outlined the important factors required for the successful use of scaffolds for cell culture and/or cell transplantation [154]. The incorporation of an extracellular matrix (ECM) is necessary to allow cell adhesion and prevent anoikis. Several investigators showed that ECM protein-coated scaffolds promote cell survival and function $[155,156]$. Induction of 
vascularization to provide a supply of oxygen and nutrients must be ensured. Transplantation within a VEGF-containing collagen scaffold significantly increased cell survival and function [157]. The material used for fabrication of a scaffold should evoke no or minimal foreign body reaction. An intense reaction can be detrimental to newly transplanted cells [158]. To this end, Goh et al. suggested the use of a decellularized pancreas as a natural 3D scaffold. After subcutaneous transplantation in mice, no evidence of a foreign body reaction was detected [159]. The shape of the implanted scaffold can also influence the inflammatory response. Mattaga et al. reported that the lowest reaction was elicited when the scaffold has a circular cross section [160]. Again, the engineering of a scaffold should allow even and uniform distribution of the loaded cells. For this purpose, Daoud and associates suggested a pore size of $\approx 350 \mu \mathrm{m}$, a spacing between strands of $\approx 400$ and a strand thickness of $\approx 100 \mu \mathrm{m}$ [147].

Two sites are suitable to provide a home for transplanted scaffolds: the subcutaneous tissue and the omentum. Smink et al. evaluated the efficiency of a subcutaneous poly-D,Llactide-co- $\varepsilon$-caprolactone (PDLLCL) scaffold for islet transplantation [161]. A 2-step procedure was adopted. Initially, the empty scaffold was implanted subcutaneously in nude mice with STZ-induced diabetes to induce vascularization. Four weeks later, rat islets were inserted into the scaffold. Transplantation of 1200 islets controlled diabetes in $100 \%$ of the treated animals. Removal of the scaffold was followed by the prompt return of hyperglycemia. The researchers concluded that a pre-vascularized scaffold can maintain the viability and function of subcutaneously transplanted cells. Pedraza and associates fabricated a microporous 3D scaffold from poly(dimethylsiloxane) (PDMS). The efficiency of islets loaded within this scaffold to restore normoglycemia was evaluated in a syngeneic diabetic rat model [162]. The omentum was used as a transplantation site. After the scaffold was placed in the omentum, $1800 \mathrm{IEQ} / \mathrm{kg}$ was loaded into the scaffold. The omentum was then wrapped around the scaffold, and the edges were sealed with fibrin gel. Transplantation of free islets in an omental pouch or under the renal capsule served as controls. Transplanted islets within the PMDS scaffold resulted in normoglycemia in $83 \%$ of the treated animals. A similar result was obtained with freely transplanted islets, whereas islets transplanted under the renal capsule reversed hyperglycemia in $100 \%$ of cases. These results indicated that the omentum is a suitable site to receive freely transplanted cells or cells loaded onto a scaffold. Similar favorable results were reported both experimentally by Berman et al. and clinically by Baidal et al. [111, 112].

In summary, subcutaneous transplantation is minimally invasive and allows retrieval of the implanted scaffolds. Its poor vascularization is a major limitation. This issue can be overcome by a 2-stage transplantation as reported by Smink et al [161]. A one-stage subcutaneous transplantation may also be possible if a drug delivery system is incorporated to provide immediate oxygenation, induce early vascularization and supply necessary growth factors. On the other hand, the vascularity of the omentum is a distinct advantage. Although transplantation into this site involves an invasive procedure, this can be minimized if a laparoscopic intervention is used.

\section{MSCs and the Immune Responses}

An intriguing feature of MSCs is their ability to evade immune recognition and inhibit immune responses [163-165]. MSCs are considered immune privileged since they lack expression of HLA class II antigens and the costimulatory molecules CD40, CD80 and CD86. The potential of MSCs for immunomodulation was recognized more than a decade ago $[166,167]$. The mechanisms involved in this immunomodulatory property are diverse and complex and were the subject of detailed reviews [168-170]. This function is evoked under inflammatory conditions and is exerted by the release of soluble factors or through cell-to-cell contact. As a proof of principle, Bartholomew and associates reported one of the first in vitro and in vivo studies [171]. When added to mitogenstimulated lymphocytes, MSCs resulted in a 50\% reduction in their proliferative activity. In vivo, administration of MSCs to mismatched recipient baboons led to prolonged allograft survival of a third-party skin graft.

The immunomodulatory functions of MSCs were explored experimentally in multiple disease models as well as in several clinical trials [172-174]. Lee et al. infused human MSCs in NOD/SCID mice with STZ-induced diabetes. The glycemic levels were reduced, and mouse but not human insulin increased. The pancreatic islets of the treated animals appeared larger, with an increase in insulin mouse reactivity [175]. Madec and coworkers injected MSCs derived from BALB-B mice into 4-week-old NOD female mice to examine the potential benefit of MSCs in cases of spontaneous diabetes [176]. The treatment delayed the onset and decreased the incidence of diabetes in $60 \%$ of the treated animals. Yang et al. isolated, expanded and differentiated human umbilical cord MSCs (hUCMSCs) to form IPCs [177]. The resulting IPCs remained hypoimmunogenic and lacked the expression of HLA class II antigens. STZ diabetes was induced in male mice. The diabetic mice were randomly assigned to receive either hUCMSCs or IPCs under the kidney capsule. The blood glucose levels of the IPC-transplanted animals decreased rapidly, while their levels remained unchanged in the hUCMSCtreated group. Thirty days post-transplantation, the removed kidneys from the IPC-transplanted animals showed infiltration by immune cells. The authors suggested that MSCs can become immunogenic after their transplantation as a result of interaction with the disease microenvironment. Changes in the allogenicity of MSCs after their differentiation and/or 
transplantation were also observed by other investigators $[178,179]$. The observed lack of consistent results can be attributed to several additional factors. The tissues from which MSCs were derived were different [180]. The routes of administration were not the same [181]. Moreover, some studies showed that allogenic MSCs are immunogenic and can evoke cell-mediated as well as humoral immune responses [182-184].

These contrasting observations emphasize the need to characterize the intricate details by which MSCs exert immunomodulation. In 2008, del Rio et al. noted the importance of programmed death receptor (PD-1) and its ligands (PD- $\mathrm{L}_{1}, \mathrm{PD}-\mathrm{L}_{2}$ ) in transplantation immunology [185]. Davies and associates reported that MSCs constitutively express $\mathrm{PD}-\mathrm{L}_{1}$ and $\mathrm{PD}-\mathrm{L}_{2}$ on their surface [186]. The proinflammatory cytokines INF and TNF $\alpha$ induce upregulation of these ligands. The receptor PD-1 is expressed on the cell surface of activated $\mathrm{T}$ and $\mathrm{B}$ cells. The interaction between PD-1 and its ligands is accomplished by cell-to-cell contact as well as by the release of soluble factors (sPD- $\mathrm{L}_{1}$ and $\mathrm{sPD}-\mathrm{L}_{2}$ ). These changes result in abrogation of interleukin-2 (IL-2) secretion, suppression of $\mathrm{T}$ cell proliferation, IL-10 production and induction of Tregs. These pathways were confirmed by blocking experiments using anti-PD-L antibodies. Additionally, splenomegaly and increased susceptibility to autoimmune disease were observed in PD-1 knockout mice [187].

The balance between the proinflammatory and immunoregulatory responses following the use of naïve or differentiated MSCs determines the final outcome. If the immunomodulatory functions of MSCs are required, the balance must be tipped towards a net regulatory function. To this end, the expression of PD-L as a biomarker to identify and select low risk-high benefit allogenic cells was recommended [188]. Furthermore, Al-Daccak and Charron suggested that banking of allogenic MSCs can allow the selection of HLA-compatible donors. The size of such a donor bank depends on the frequency of HLA haplotypes. It is estimated that storing $\approx 100$ haplotypes would allow the selection of a compatible donor [189]. It was also advocated that among the suitable allogenic cells, donor-specific antibodies have to be excluded by Luminexbased solid-phase assays [190]. Although these findings are significant, they should not be generalized and have to be carefully verified when IPCs derived from MSCs are considered for clinical application.

\section{Concluding Remarks}

The aim of this review is to identify challenges facing transplantation of hMSC-derived IPCs as a potential cell therapy for type $1 \mathrm{DM}$. MSCs offer several advantages over other cell sources. Their risk of teratogenicity is negligible. Verification of their immunomodulatory function would prevent the need for life-long immunosuppression or encapsulation within an immunoisolation device. In addition, the efficiency of hMSCderived IPCs to control chemically induced diabetes in experimental animals is comparable to that of pluripotent stem cellderived $\beta$ cells.

MSCs can be obtained from an autologous source. Allogenic hAT-MSCs are a widely available by-product of cosmetic surgeries and should not be wasted. Samples can be stored, and their immunologic identity can be determined to select the optimal donor cells.

For clinical application, 2 sites can provide a suitable home for the transplanted cells: the subcutaneous tissue or the omentum. A 2-stage procedure is required for the former and a laparoscopic intervention for the latter. For either site, cells must be transplanted within a scaffold. Thus far, a biological scaffold from fibrin is adequate for the required goal. In this regard, the initial success of the clinical trial reported by Baidal et al. using the omentum as a transplantation site shows promise [112].

Over the past decade, significant progress has been achieved in the experimental domain. For clinical translation, several issues have to be resolved. Will MSC-derived IPCs retain their immunomodulatory function or become immunogenic? Will they be susceptible to the detrimental effects of existing antibodies that have destroyed the native $\beta$ cells in type $1 \mathrm{DM}$ ? What will be the functional longevity after transplantation? Finally, it must be emphasized that cell therapy for type $1 \mathrm{DM}$ can only be meaningful and clinically justifiable if their functional results are comparable to or better than those of the ever-improving closed-loop insulin pumps.

Acknowledgement The authors would like to thank Mrs. Ahlam Saad for her excellent secretarial work.

\section{Author's Contributions}

MAG Wrote the manuscript

AFR Revised and arranged references

BLE Revised the manuscript

MMG Revised the section on directed differentiation

MMZ Revised the section on gene differentiation

\section{Compliance with ethical standards}

Conflict of interest The authors declare that there is no conflict of interest

Open Access This article is licensed under a Creative Commons Attribution 4.0 International License, which permits use, sharing, adaptation, distribution and reproduction in any medium or format, as long as you give appropriate credit to the original author(s) and the source, provide a link to the Creative Commons licence, and indicate if changes were made. The images or other third party material in this article are included in the article's Creative Commons licence, unless indicated otherwise in a credit line to the material. If material is not included in the article's Creative Commons licence and your intended use is not permitted by statutory regulation or exceeds the permitted use, you will need to obtain 
permission directly from the copyright holder. To view a copy of this licence, visit http://creativecommons.org/licenses/by/4.0/.

\section{References}

1. Roglic, G. (2016). Report on diabetes: a summary. International Journal of noncommunicable disease, 1(1), 3 .

2. Soria, B., Roche, E., Berná, G., León-Quinto, T., Reig, J. A., \& Martín, F. (2000). Insulin-secreting cells derived from embryonic stem cells normalize glycemia in streptozotocin-induced diabetic mice. Diabetes, 49(2), 157-162. https://doi.org/10.2337/diabetes. 49.2.157.

3. Lumelsky, N., Blondel, O., Laeng, P., Velasco, I., Ravin, R., \& McKay, R. (2001). Differentiation of embryonic stem cells to insulin-secreting structures similar to pancreatic islets. Science, 292(5520), 1389-1394. https://doi.org/10.1126/science.1058866.

4. Segev, H., Fishman, B., Ziskind, A., Shulman, M., \& ItskovitzEldor, J. (2004). Differentiation of human embryonic stem cells into insulin-producing clusters. Stem Cells, 22(3), 265-274. https://doi.org/10.1634/stemcells.22-3-265.

5. Rajagopal, J., Anderson, W. J., Kume, S., Martinez, O. I., \& Melton, D. A. (2003). Insulin staining of ES cell progeny from Insulin uptake. Science, 299(5605), 363. https://doi.org/10.1126/ science. 1077838.

6. Kubo, A., Shinozaki, K., Shannon, J. M., Kouskoff, V., Kennedy, M., Woo, S., et al. (2004). Development of definitive endoderm from embryonic stem cells in culture. Development, 131(7), 16511662. https://doi.org/10.1242/dev.01044.

7. D'Amour, K. A., Agulnick, A. D., Eliazer, S., Kelly, O. G., Kroon, E., \& Baetge, E. E. (2005). Efficient differentiation of human embryonic stem cells to definitive endoderm. Nature Biotechnology, 23(12), 1534-1541. https://doi.org/10.1038/ nbt1163.

8. Kroon, E., Martinson, L. A., Kadoya, K., Bang, A. G., Kelly, O. G., Eliazer, S., et al. (2008). Pancreatic endoderm derived from human embryonic stem cells generates glucose-responsive insulin-secreting cells in vivo. Nature Biotechnology, 26(4), 443-452. https://doi.org/10.1038/nbt1393.

9. Schulz, T. C. (2015). Concise Review: Manufacturing of Pancreatic Endoderm Cells for Clinical Trials in Type 1 Diabetes. Stem cell translational medicine, 4(8), 927-931. https://doi.org/10.5966/sctm.2015-0058.

10. Rezania, A., Bruin, J. E., Arora, P., Rubin, A., Batushansky, I., Asadi, A., et al. (2014). Reversal of diabetes with insulinproducing cells derived in vitro from human pluripotent stem cells. Nature Biotechnology, 32(11), 1121-1133. https://doi.org/10. 1038/nbt.3033.

11. Pagliuca, F. W., Millman, J. R., Gürtler, M., Segel, M., Dervort, A. V., Ryu, J. H., et al. (2014). Generation of functional human pancreatic $\beta$-cells in vitro. Cell, 159(2), 428-439. https://doi.org/ 10.1016/j.cell.2014.09.040.

12. Digirolamo, C. M., Stokes, D., Colter, D., Phinney, D. G., Class, R., \& Prockop, D. J. (1999). Propagation and senescence of human marrow stromal cells in culture: A simple colony-forming assay identifies samples with the greatest potential to propagate and differentiate. British Journal of Haematology, 1999, 107(2), 275-281. https://doi.org/10.1046/j.1365-2141.1999.01715.x.

13. Nombela-Arrieta, C., Ritz, J., \& Silberstein, L. E. (2011). The elusive nature and function of mesenchymal stem cells. Nature Reviews of Molecular Cell Biology, 12(2), 126-131. https://doi. org/10.1038/nrm3049.
14. Casiraghi, F., Remuzzi, G., Abbate, M., \& Perico, N. (2013). Multipotent mesenchymal stromal cell therapy and risk of malignancies. Stem cell reviews and reports, 9(1), 65-79. https://doi. org/10.1007/s12015-011-9345-4.

15. Samsonraj, R. M. Raghunath, M., Nurcombe, V., Hui, J. H., van Wijnen, A. j., et al. (2017), Concise review: multifaceted characterization of human mesenchymal stem cells for use in regenerative medicine. Stem Cells Translational Medicine, 6(12), 21732185. https://doi.org/10.1002/sctm.17-0129

16. Friedenstein, A. J., Piatetzky-Shapiro, I. I., \& Petrakova, K. N. (1966). Osteogenesis on transplants of bone marrow cells. Journal of Embryology and Experimental Morphology, 16(3), 381-390.

17. Owen, M. (1988). Marrow stromal stem cells. Journal of Cell Science, Suppl, 10, 63-76. https://doi.org/10.1242/jcs.1988. supplement_10.5.

18. Caplan, A. I. (1991). Mesenchymal stem cells. Journal of Orthopaedic Research, 9(5), 641-650. https://doi.org/10.1002/ jor.1100090504.

19. Horwitz, E. M., \& Keating, A. (2000). Nonhematopoietic mesenchymal stem cells: what are they? Cytotherapy, 2(5), 387-388. https://doi.org/10.1080/146532400539305.

20. Horwitz, E. M., Le Blanc, K., Dominici, M., Mueller, I., SlaperCortenbach, I., Marini, F. C., et al. (2005). Clarification of the nomenclature for msc: the international society for cellular therapy position statement. Cytotherapy, 7(5), 393-395. https://doi.org/ 10.1080/14653240500319234.

21. Dominici, M., Le Blanc, K., Mueller, I., Slaper-Cortenbach, I., Marini, F., Krause, D., et al. (2006). Minimal criteria for defining multipotent mesenchymal stromal cells. The international society for cellular therapy position statement. Cytotherapy, 8(4), 315317. https://doi.org/10.1080/14653240600855905.

22. Wagner, W., Ho, D., \& A. (2007). Mesenchymal stem cell preparations-comparing apples and oranges. Stem Cell Reviews and Reports, 3(4), 239-248. https://doi.org/10.1007/s12015-0079001-1.

23. Lv, F., Tuan, R. S., Cheung, K. M., \& Leung, V. Y. (2014). Concise review: The surface markers and identity of human mesenchymal stem cells. Stem Cells, 32(6), 1408-1419. https://doi. org/10.1002/stem.1681.

24. Muraglia, A., Cancedda, R., \& Quarto, R. (2000). Clonal mesenchymal progenitors from human bone marrow differentiate in vitro according to a hierarchical model. Journal of Cell Science, 113(Pt 7), 1161-1166.

25. Reyes, M., Lund, T., Lenvik, T., Aguiar, D., Koodie, L., \& Verfaillie, C. M. (2001). Purification and ex vivo expansion of postnatal human marrow mesodermal progenitor cells. Blood, 98(9), 2615-2625. https://doi.org/10.1182/blood.V98.9.2615.

26. Retraction. Reyes, M., Lund, T., Lenvik, T., Aguiar, D., Koodie, L., \& Verfaillie, C.M. (2009). Purification and ex vivo expansion of postnatal human marrow mesodermal progenitor cells. Blood, 113(10), 2370. https://doi.org/10.1182/blood-2008-10-186288.

27. Kögler, G., Sensken, S., Airey, J. A., Trapp, T., Müschen, M., Feldhahn, N., et al. (2004). A new human somatic stem cell from placental cord blood with intrinsic pluripotent differentiation potential. Journal of Experimental Medicine, 200(2), 123-135. https://doi.org/10.1084/jem.20040440.

28. D'Ippolito, G., Diabira, S., Howard, G. A., Menei, P., Roos, B. A., \& Schiller, P. C. (2004). Marrow-isolated adult multilineage inducible (MIAMI) cells, a unique population of postnatal young and old human cells with extensive expansion and differentiation potential. Journal of Cell Science, 117(Pt 14), 2971-2981. https:// doi.org/10.1242/jcs.01103.

29. Kucia, M., Wysoczynski, M., Ratajczak, J., \& Ratajczak, M. Z. (2008). Identification of very small embryonic like (VSEL) stem 
cells in bone marrow. Cell and Tissue Research, 331(1), 125-134. https://doi.org/10.1007/s00441-007-0485-4.

30. Kuroda, Y., Kitada, M., Wakao, S., Nishikawa, K., Tanimura, Y., Makinoshima, H., et al. (2010). Unique multipotent cells in adult human mesenchymal cell populations. Proceedings of the National Academy of Sciences of the United States of America, 107(19), 8639-8643. https://doi.org/10.1073/pnas.0911647107.

31. Corselli, M., Chen, C., Crisan, M., Lazzari, L., \& Péault, B. (2010). Perivascular Ancestors of Adult Multipotent Stem Cells. Arteriosclerosis Thrombosis and Vascular Biology, 30(6), 1104 1109. https://doi.org/10.1161/ATVBAHA.109.191643.

32. Hirschi, K. K., \& D'Amore, P. A. (1996). Pericytes in the microvasculature. Cardiovascular Research, 32(4), 687-698. https:// doi.org/10.1016/S0008-6363(96)00063-6.

33. Bara, J. J., Richards, R. G., Alini, M., \& Stoddart, M. J. (2014). Concise review: Bone marrow-derived mesenchymal stem cells change phenotype following in vitro culture: implications for basic research and the clinic. Stem Cells, 32(7), 1713-1723. https://doi. org/10.1002/stem.1649.

34. Blocki, A., Wang, Y., Koch, M., Peh, P., Beyer, S., Law, P., et al. (2013). Functional in vitro assays to distinguish pericytes from other mesenchymal stem cells in angiogenesis. Stem Cells and Development, 22(17), 2347-2355. https://doi.org/10.1089/scd. 2012.0415.

35. Mu, X., Ren, L., Yan, H., Zhang, X., Xu, W., \& A., et al. (2017). Enhanced differentiation of human amniotic fluid-derived stem cells into insulin-producing cells in vitro. Journal of Diabetes Investigation, 8(1), 34-43. https://doi.org/10.1111/jdi.12544.

36. Wu, L., Wang, N., Liu, Y., \& Xing Wei, X. (2009). Differentiation of Wharton's Jelly primitive stromal cells into insulin-producing cells in comparison with bone marrow mesenchymal stem cells. Tissue Engineering Part A, 15(10), 2865-2873. https://doi.org/10. 1089/ten.TEA.2008.0579.

37. Wang, H., Shyu, J., Shen, W., Hsu, H., Chi, T., et al. (2011). Transplantation of insulin-producing cells derived from umbilical cord stromal cord stromal mesenchymal stem cells to treat NOD Mice. Cell Transplantation, 20(3), 455-466. https://doi.org/10. 3727/096368910X522270.

38. Chandravanshi, B., \& Bhonde, R. R. (2018). Human umbilical cord-derived stem cells: isolation, characterization, differentiation, and application in treating diabetes. Critical Reviews in Biomedical Engineering, 46(5), 399-412. https://doi.org/10. 1615/CritRevBiomedEng.2018027377.

39. Samani, F. S., Ebrahimi, M., Zandieh, T., Khoshchehreh, R., Baghaban, Eslaminejad, M. B., et al. (2015). In vitro differentiation of human umbilical cord blood cd133 (+) cells into insulin producing cells in co-culture with rat pancreatic mesenchymal stem cells. Cell Journal, 17(2), 211-220. 10.22074/ cellj.2016.3717

40. Fukuchi, Y., Nakajima, H., Sugiyama, D., Hirose, I., Kitamura, T., \& Tsuji, K. (2004). Human placenta-derived cells have mesenchymal stem/progenitor cell potential. Stem Cells, 22(5), 649-658. https://doi.org/10.1634/stemcells.22-5-649.

41. Sun, Y., Chen, L., Hou, X., Hou, W., Dong, J., Sun, L., et al. (2007). Differentiation of bone marrow-derived mesenchymal stem cells from diabetic patients into insulin-producing cells in vitro. Chinese Medical Journal, 120(9), 771-776.

42. Gabr, M. M., Zakaria, M. M., Refaie, A. F., Ismail, A. M., AbouEl-Mahasen, M. A., Ashamallah, S. A., et al. (2013). Insulinproducing cells from adult human bone marrow mesenchymal stem cells control streptozotocin-induced diabetes in nude mice. Cell Transplantation, 22(1), 133-145. https://doi.org/10.3727/ 096368912 X647162.

43. Czubak, P., Bojarska-Junak, A., Tabarkiewicz, J., \& Putowski, L. (2014). A modified method of insulin producing cells' generation from bone marrow-derived mesenchymal stem cells. Journal of
Diabetes Research, 2014, 628591. https://oi.org/10.1155/2014/ 628591.

44. Khorsandi, L., Nejad-Dehbashi, F., Ahangarpour, A., \& Hashemitabar, M. (2015). Three-dimensional differentiation of bone marrow derived mesenchymal stem cells into insulinproducing cells. Tissue and Cell, 47(1), 66-72. https://doi.org/ 10.1016/j.tice.2014.11.005.

45. Xin, Y., Jiang, X., Wang, Y., Su, X., Sun, M., Zhang, L., et al. (2016). Insulin-producing cells differentiated from human bone marrow mesenchymal stem cells in vitro ameliorate streptozotocin-induced diabetic hyperglycemia. PLoS One, 11(1), e 0145838. https://doi.org/10.1371/journal.pone.0145838.

46. Daryabor, G., Shiri, E. H., \& Kamali-Sarvestani, E. (2019). A simple method for the generation of insulin producing cells from bone marrow mesenchymal stem cells. In Vitro Cellular \& Developmental Biology - Animal, 55(6), 462-471. https://doi. org/10.1007/s11626-019-00358-z.

47. Timper, K., Seboek, D., Eberhardt, M., Linscheid, P., ChristCrain, M., Keller, U., et al. (2006). Human adipose tissuederived mesenchymal stem cells differentiate into insulin, somatostatin, and glucagon expressing cells. Biochemical and Biophysical Research Communications, 341(4), 135-140. https://doi.org/10.1016/j.bbrc.2006.01.072.

48. Moshtagh, P. R., Emami, S. H., \& Sharifi, A. M. (2013). Differentiation of human adipose-derived mesenchymal stem cell into insulin-producing cells: an in vitro study. Journal of physiology and biochemistry, 69(3), 451-458. https://doi.org/10.1007/ s13105-012-0228-1.

49. Karaoz, E., Okcu, A., Ünal, Z. S., Subasi, C., Saglam, O., \& Duruksu, G. (2013). Adipose tissue-derived mesenchymal stromal cells efficiently differentiate into insulin-producing cells in pancreatic islet microenvironment both in vitro and in vivo. Cytotherapy, 15(5), 557-570. https://doi.org/10.1016/j.jcyt.2013. 01.005 .

50. Sawangmake, C., Nowwarote, N., Pavasant, P., Chansiripornchai, P., \& Osathanon, T. (2014). A feasibility study of an in vitro differentiation potential toward insulin-producing cells by dental tissue-derived mesenchymal stem cells. Biochemical and Biophysical Research Communications, 452(3), 581-587. https://doi.org/10.1016/j.bbrc.2014.08.121.

51. Suchanek, J., Nasry, S. A., \& Soukup, T. (2017). The differentiation potential of human natal dental pulp stem cells into insulinproducing cells. Folia Biologica (Praha), 63(4), 132-138.

52. Kim, S., Kim, Y., Park, W., Kim, H. S., Jung, S., Woo, S., et al. (2015). Characterization of insulin-producing cells differentiated from tonsil derived mesenchymal stem cells. Differentiation, 90(1-3), 27-39. https://doi.org/10.1016/j.diff.2015.08.001.

53. Santamaria, X., Massasa, E. E., Feng, Y., Wolff, E., \& Taylor, H. S. (2011). Derivation of insulin producing cells from human endometrial stromal stem cells and use in the treatment of murine diabetes. Molecular Therapy, 19(11), 2065-2071. https://doi.org/ 10.1038/mt.2011.173.

54. Dao, L. T., Park, E., Lim, S., Choi, Y., Jung, H. S., \& Jun, H. (2014). Transplantation of insulin-producing cells differentiated from human periosteum-derived progenitor cells ameliorate hyperglycemia in diabetic mice. Transplantation, 98(10), 1040 1047. https://doi.org/10.1097/TP.0000000000000388.

55. Shaowei Li, S., Huang, K., Wu, J., Hu, M. S., Sanyal, M., Hu, M., et al. (2015). Peripheral blood-derived mesenchymal stem cells: candidate cells responsible for healing critical-sized calvarial bone defects. Stem Cells Translational Medicine, 4(4), 359-368. https:// doi.org/10.5966/sctm.2014-0150.

56. Meivar-Levy, I., \& Ferber, S. (2015). Reprogramming of liver cells into insulin-producing cells. Best Practice \& Research Clinical Endocrinology \& Metabolism, 29(6), 873-882. https:// doi.org/10.1016/j.beem.2015.10.006. 
57. Strem, B. M., Hicok, K. C., Zhu, M., Wulur, I., Alfonso, Z., Schreiber, R. E., et al. (2005). Multipotential differentiation of adipose tissue-derived stem cells. The Keio Journal of Medicine, 54(3), 132-141. https://doi.org/10.2302/kjm.54.132.

58. Ranjbaran, H., Abediankenari, S., Khalilian, A., Rahmani, Z., Momeninezhad Amiri, M., \& Hosseini Khah, Z. (2018). Differentiation of Wharton's Jelly derived Mesenchymal stem cells into insulin producing cells. International Journal of Hematology-Oncology and Stem Cell Research, 12(3), 220-229.

59. Kamal, M. M., \& Kassem, D. H. (2020). Therapeutic potential of Wharton's Jelly mesenchymal stem cells for diabetes: achievements and challenges. Frontiers in cell and developmental biology, 8, 16. https://doi.org/10.3389/fcell.2020.00016.

60. Chao, K. C., Chao, K. F., Fu, Y. S., \& Liu, S. H. (2008). Islet-like clusters derived from mesenchymal stem cells in Wharton's Jelly of the human umbilical cord for transplantation to control type 1 diabetes. PLoS one, 3(1), e1451. https://doi.org/10.1371/journal. pone.0001451.

61. Gabr, M. M., Zakaria, M. M., Refaie, A. F., Abdel-Rahman, E. A., Reda, A. M., Ali, S. S., et al. (2017). From human mesenchymal stem cells to insulin-producing cells: comparison between bone marrow- and adipose tissue-derived cells. Biomed Research International, 2017, 3854232. https://doi.org/10.1155/2017/ 3854232.

62. Chan, T., Harn, H., Lin, H., Chou, P., Chen, J., Ho, T., et al. (2014). Improved human mesenchymal stem cell isolation. Cell Transplantation, 23(4-5), 399-406. https://doi.org/10.3727/ 096368914 X678292.

63. Ferrin, I., Beloqui, I., Zabaleta, L., Salcedo, J. M., Trigueros, C., \& Martin, A. G. (2017). Isolation, culture, and expansion of mesenchymal stem cells. Methods in Molecular Biology (Clifton, N.J.), 1590, 177-190. https://doi.org/10.1007/978-1-4939-6921-0 13.

64. Calne, R., \& Ghoneim, M. A. (2010). Novel diabetes therapy: The seven pillars of credibility. Treatment Strategies Diabetes. www. treatmentstrategies.co.uk/diabetes.html

65. Chen, N. K., Wong, J. S., Kee, I. H., Lai, S. H., Thng, C. H., Ng, W. H., et al. (2008). Nonvirally modified autologous primary hepatocytes correct diabetes and prevent target organ injury in a large preclinical model. PLoS One, 3(30), e1734. https://doi.org/ 10.1371/journal.pone.0001734.

66. Ren, B., O'Brien, B. A., Swan, M. A., Koina, M. E., Nassif, N., Wei, M. Q., et al. (2007). Long-term correction of diabetes in rats after lentiviral hepatic insulin gene therapy. Diabetologia, 50(9), 1910-1920. https://doi.org/10.1007/s00125-007-0722-0.

67. Karnieli, O., Izhar-Prato, Y., Bulvik, S., \& Efrat, S. (2007). Generation of insulin-producing cells from human bone marrow mesenchymal stem cells by genetic manipulation. Stem Cells, 25(11), 2837-2844. https://doi.org/10.1634/stemcells.2007-0164.

68. Guo, Q. S., Zhu, M. Y., Wang, L., Fan, X. J., Lu, Y. H., Wang, Z. W., et al. (2012). Combined transfection of the three transcriptional factors, pdx-1, neurod1, and MafA, causes differentiation of bone marrow mesenchymal stem cells into insulin-producing cells. Experimental Diabetes Research, 2012, https://doi.org/10. 1155/2012/672013.

69. Boroujeni, Z. N., \& Aleyasin, A. (2013). Insulin producing cells established using non-integrated lentiviral vector harboring PDX1 gene. World Journal of Stem Cells, 5(4), 217-228. https://doi.org/ 10.4252/wjsc.v5.i4.217.

70. Thi Do, H. V., Loke, V. T., Kee, I., Liang, V., David, S. J., Gan, S. U., et al. (2015). Characterization of insulin-secreting porcine bone marrow stromal cells ex vivo and autologous cell therapy in vivo. Cell Transplantation, 24(7), 1205-1220. https://doi.org/ 10.3727/096368914X679363.

71. Jafarian, A., Taghikani, M., Abroun, S., Allahverdi, A., Lamei, M., Lakpour, N., et al. (2015). The generation of insulin producing cells from human mesenchymal stem cells by MiR-375 and Anti-
MiR-9. PLoS One, 10(6), e0128650. https://doi.org/10.1371/ journal.pone.0128650.

72. Bai, C., Gao, Y., Li, X., Wang, K., Xiong, H., Shan, Z., et al. (2017). MicroRNAs can effectively induce formation of insulinproducing cells from mesenchymal stem cells. Journal of Tissue Engineering and Regenerative Medicine, 11(12), 3457-3468. https://doi.org/10.1002/term.2259.

73. Mas, A., Montané, J., Anguela, X. M., Muñoz, S., Douar, A. M., Riu, E., et al. (2006). Reversal of type 1 diabetes by engineering a glucose sensor in skeletal muscle. Diabetes, 55(6), 1546-1553. https://doi.org/10.2337/db05-1615.

74. Callejas, D., Mann, C. J., Ayuso, E., Lage, R., Grifoll, I., Roca, C., et al. (2013). Treatment of diabetes and long-term survival after insulin and glucokinase gene therapy. Diabetes, 62(5), 17181729. https://doi.org/10.2337/db12-1113.

75. Jaén, M. L., Vilà, L., Elias, I., Jimenez, V., Rodó, J., Maggioni, L., et al. (2017). Long-term efficacy and safety of insulin and glucokinase gene therapy for diabetes: 8 -year follow-up in dogs. Molecular Therapy - Methods \& Clinical Development, 6, 1-7. https://doi.org/10.1016/j.omtm.2017.03.008.

76. Benabdellah, K., Sánchez-Hernández, S., Aguilar-González, A., Maldonado-Pérez, N., Gutierrez-Guerrero, A., Cortijo-Gutierrez, M., et al. (2020). Genome-edited adult stem cells: next-generation advanced therapy medicinal products (ATMPs). Stem Cells Translational Medicine, 6, [Online ahead of print]. https://doi. org/10.1002/sctm.19-0338.

77. Cong, L., Ran, F. A., Co, D., Lin, S., Barreto, R., Habib, N., et al. (2013). Multiplex genome engineering using CRISPR/Gas systems. Science, 339(6121), 819-823. https://doi.org/10.1126/ science.1231143.

78. Mali, P., Yang, L., Esvelt, K. M., Aach, J., Guell, M., DiCarlo, J. E., et al. (2013). RNA-guided human genome engineering via Cas9. Science, 339(6121), 823-826. https://doi.org/10.1126/ science. 1232033.

79. Hsu, P. D., Lander, E. S., \& Zhang, F. (2014). Development and applications of CRISPR- Cas9 for genome engineering. Cell, 157(6), 1262-1278. https://doi.org/10.1016/j.cell.2014.05.010.

80. Kabadi, A. M., Ousterout, D. G., Hilton, I. B., \& Gersbach, C. A. (2014). Multiplex CRISPR/Cas9-based genome engineering from a single lentiviral vector. Nucleic Acids Research, 42(19), e147. https://doi.org/10.1093/nar/gku749.

81. Giménez, C. A., Ielpi, M., Mutto, A., Grosembacher, L., Argibay, P., \& Pereyra-Bonnet, F. (2016). CRISPR-on system for the activation of the endogenous human INS gene. Gene Therapy, 23(6), 543-547. https://doi.org/10.1038/gt.2016.28.

82. Zhu, Z., Li, Q. V., Lee, K., Rosen, B. P., González, F., Soh, C., et al. (2016). Genome editing of lineage determinants in human pluripotent stem cells reveals mechanisms of pancreatic development and diabetes. Cell Stem Cell, 18(6), 755-768. https://doi.org/ 10.1016/j.stem.2016.03.015.

83. Ma, S., Viola, R., Sui, L., Cherubini, V., Barbetti, F., \& Egli, D. (2018). $\beta$ cell replacement after gene editing of a neonatal diabetes-causing mutation at the insulin locus. Stem Cell, 11(6), 1407-1415. https://doi.org/10.1016/j.stemcr.2018.11.006.

84. Makino, S., Fukuda, K., Miyoshi, S., Konishi, F., Kodama, H., Pan, J., et al. (1999). Cardiomyocytes canbe generated from marrow stromal cells in vitro. Clinical Investigations, 103(5), 697705. https://doi.org/10.1172/JCI5298.

85. Oswald, J., Boxberger, S., Jørgensen, B., Feldmann, S., Ehninger, G., Bornhäuser, M., et al. (2004). Mesenchymal stem cells can be differentiated into endothelial cells in vitro. Stem Cells, 22(3), 377-384. https://doi.org/10.1634/stemcells.22-3-377.

86. Snykers, S., Kock, J. D., Rogiers, V., \& Vanhaecke, T. (2009). In vitro differentiation of embryonic and adult stem cells into hepatocytes: state of the art. Stem Cells, 27(3), 577-605. https:// doi.org/10.1634/stemcells.2008-0963. 
87. Tang, D. Q., Cao, L. Z., Burkhardt, B. R., Xia, C. Q., Litherland, S. A., Atkinson, M. A., et al. (2004). In vivo and in vitro characterization of insulin-producing cells obtained from murine bone marrow. Diabetes, 53(7), 1721-1732. https://doi.org/10.2337/ diabetes.53.7.1721.

88. Chen, L. B., Jiang, X. B., \& Yang, L. (2004). Differentiation of rat marrow mesenchymal stem cells into pancreatic islet beta-cells. World Journal of Gastroenterology, 10(20), 3016-3020. https:// doi.org/10.3748/wjg.v10.i20.3016.

89. Oh, S. H., Muzzonigro, T. M., Bae, S. H., LaPlante, J. M., Hatch, H. M., \& Petersen, B. E. (2004). Adult bone marrow-derived cells trans-differentiating into insulin-producing cells for the treatment of type I diabetes. Laboratory Investigations., 84(5), 607-617. https://doi.org/10.1038/labinvest.3700074.

90. Chandra, V. G., Phadnis, S., Nair, P. D., \& Bhonde, R. R. (2009). Generation of pancreatic hormone-expressing islet-like cell aggregates from murine adipose tissue-derived stem cells. Stem Cells, 27(8), 1941-1953. https://doi.org/10.1002/stem.117.

91. Takemitsu, H., Zhao, D., Ishikawa, S., Michishita, M., Arai, T., \& Yamamoto, I. (2013). Mechanism of insulin production in canine bone marrow derived mesenchymal stem cells. General and Comparative Endocrinology, 189, 1-6. https://doi.org/10.1016/j. ygcen.2013.04.009.

92. Sun, Y., Zhang, M., Ji, S., \& Liu, L. (2015). Induction differentiation of rabbit adipose derived stromal cells into insulin producing cells in vitro. Molecular Medicine Reports, 12(5), 6835-6840. https://doi.org/10.3892/mmr.2015.4305.

93. Gabr, M. M., Zakaria, M. M., Refaie, A. F., Khater, S. M., Ashamallah, S. A., Ismail, A. M., et al. (2014). Generation of insulin-producing cells from human bone marrow-derived mesenchymal stem cells: comparison of three differentiation protocols. Biomed Research International, 2014, 832736. https://doi.org/10. 1155/2014/832736.

94. Thatava, T., Ma, B., Rohde, M., \& Mayer, H. (2006). Chromatinremodeling factors allow differentiation of bone marrow cells into insulin-producing cells. Stem Cells, 24(12), 2858-2867. https:// doi.org/10.1634/stemcells.2006-0109.

95. Gabr, M. M., Zakaria, M. M., Refaie, A. F., Khater, S. M., Ashamallah, S. A., Ismail, A. M., et al. (2015). Differentiation of human bone marrow derived mesenchymal stem cells into insulin-producing cells: evidence for further maturation in vivo. Biomed Research International, 2015, 575837. https://doi.org/10. 1155/2015/575837.

96. Enderami, S. E., Soleimani, M., Mortazavi, Y., Nadri, S., \& Salimi, A. (2018). Generation of insulin-producing cells from human adipose derived mesenchymal stem cells on PVA scaffold by optimized differentiation protocol. Journal of Cell Physiology, 233(5), 4327-4337. https://doi.org/10.1002/jcp.26266.

97. Pokrywczynska, M., Lewandowska, M. A., Krzyzanowska, S., Jundzill, A., Rasmus, M., Warda, K., et al. (2015). Transdifferentiation of bone marrow mesenchymal stem cells into the islet-like cells: The role of extracellular matrix proteins. Archivum immunologiae et therapiae experimentalis (Warsz), 63(5), 377-384. https://doi.org/10.1007/s00005-015-0340-3.

98. Choi, K. S., Shin, J. S., Lee, J. J., Kim, Y. S., Kim, S. B., \& Kim, C. W. (2005). In vitro transdifferentiation of rat mesenchymal cells into insulin-producing cells by rat pancreatic extract. Biochemical and Biophysical Research Communications, 330(4), 1299-1305. https://doi.org/10.1016/j.bbrc.2005,03.111.

99. Xie, H., Wang, Y., Zhang, H., Qi, H., Zhou, H., \& Li, F. R. (2013). Role of injured pancreatic extract promotes bone marrow-derived mesenchymal stem cells efficiently differentiate into insulinproducing cells. PLoS One, 8(9), e76056. https://doi.org/10. 1371/journal.pone.0076056.

100. Xie, H., Zhang, H., Qi, H., Wang, Y., Deng, C., \& Li, F. R. (2013). Discovery of novel proteins form injured rat pancreatic extract using MALDI-TOF/MS- based proteomics. Journal of Proteomics \& Bioinformatics, 6(8), 158-163. https://doi.org/10. 4172/jpb.1000275.

101. Gabr, M. M., Zakaria, M. M., Refaie, A. F., Khater, S. M., Ashamallah, S. A., Rashed, S. A., et al. (2020). PRDX6 promotes the differentiation of human mesenchymal stem (stromal) cells to insulin-producing cells. Biomed Research International, 2020, 7103053. https://doi.org/10.1155/2020/7103053.

102. Cantarelli, E., \& Piemonti, L. (2011). Alternative transplantation sites for pancreatic islet grafts. Current Diabetes Reports, 11(5), 364-374. https://doi.org/10.1007/s11892-011-0216-9.

103. Vériter, S., Gianello, P., \& Dufrane, D. (2013). Bioengineered sites for islet cell transplantation. Current Diabetes Reports, 13(5), 745-755. https://doi.org/10.1007/s1 1892-013-0412-x.

104. Zhu, H., Li, W., Liu, Z., Li, W., Chen, N., Lu, L., et al. (2018). Selection of implantation sites for transplantation of encapsulated pancreatic islets. Tissue Engineering Part B: Reviews, 24(3), 191214. https://doi.org/10.1089/ten.TEB.2017.0311.

105. Welsch, C. A., Rust, W. L., \& Csete, M. (2019). Concise Review: lessons learned from islet transplant clinical trials in developing stem cell therapies for type 1 diabetes. Stem Cells Translational Medicine, 8(3), 209-214. https://doi.org/10.1002/sctm.18-0156.

106. Pepper, A. R., Gala-Lopez, B., Pawlick, R., Merani, S., Kin, T., \& Shapiro, J. (2015). A Prevascularized subcutaneous device-less site for islet and cellular transplantation. Nature Biotechnology, 33(5), 518-523. https://doi.org/10.1038/nbt.3211.

107. Svensson, J., Lau, J., Sandberg, M., \& Carlsson, P. O. (2011). High vascular density and oxygenation of pancreatic islets transplanted in clusters into striated muscle. Cell Transplantation, 20(5), 783-788. https://doi.org/10.3727/ $096368910 X 536527$.

108. Yasunami, Y., Lacy, P. E., \& Finke, E. H. (1983). A New site for islet transplantation-a peritoneal-omental pouch. Transplantation, 1983, 36(2), 181-182. https://doi.org/10.1097/00007890198308000-00014

109. Kim, H. I., Yu, J. Y., Park, C. G., \& Kim, \& S. J. (2010). Comparison of four pancreatic islet implantation sites. Journal of Korean Medical Science, 25(2), 203-210. https://doi.org/10. 3346/jkms.2010.25.2/203.

110. Bartholomeus, K., Thevissen, D. J., Shouyue, S., Suenens, K., In't Veld, P. A., Marichal, M. P., Pipeleers, D. G., et al. (2013). Omentum is better site than kidney capsule for growth, differentiation, and vascularization of immature porcine $\beta$-cell implants in immunodeficient rats. Transplantation, 96(12), 1026-1033. https://doi.org/10.1097/TP.0b013e3182a6ee41.

111. Berman, B. M., Molano, R. D., Fotino, C., Ulissi, U., Gimeno, J., et al. (2016). Bioengineering the endocrine pancreas: intraomental islet transplantation within a biologic resorbable scaffold. Diabetes, 65(5), 1350-1361. https://doi.org/10.2337/db15-1525.

112. Baidal, D. A., Ricordi, C., Berman, D. M., Alvarez, A., Padilla, N., Ciancio, G., et al. (2017). Bioengineering of an Intraabdominal Endocrine Pancreas. New England Journal of Medicine, 376(19), 1887-1889. https://doi.org/10.1056/NEJMc1613959.

113. Lim, F., \& Sun, A. M. (1980). Microencapsulated islets as bioartificial endocrine pancreas. Science, 210(4472), 908-910. https://doi.org/10.1126/science.6776628.

114. Tomei, A. A., Villa, C., \& Ricordi, C. (2015). Development of an encapsulated stem cell-based therapy for diabetes. Expert Opinion on Biological Therapy, 15(9), 1321-1336. https://doi.org/10. 1517/14712598.2015.1055242.

115. de Groot, M., Schuurs, T. A., van Schilfgaarde, R. (20040. Causes of limited survival of microencapsulated pancreatic islet grafts. Journal of Surgical Research, 121(1), 141-150. https://doi.org/ 10.1016/j.jss.2004.02.018

116. Soon-Shiong, P., Heintz, R. E., Merideth, N., Yao, Q. X., Yao, Z., et al. (1994). Insulin independence in a type 1 diabetic patient after 
encapsulated islet transplantation. Lancet, 343(8903), 950-951. https://doi.org/10.1016/s0140-6736(94)90067-1.

117. Dang, T. T., Thai, A. V., Cohen, J., Slosberg, J. E., Siniakowicz, K., Doloff, J. C., et al. (2013). Enhanced function of immunoisolated islets in diabetes therapy by co-encapsulation with an anti-inflammatory drug. Biomaterials, 34(23), 5792-5801. https://doi.org/10.1016/j.biomaterials.2013.04.016.

118. Tomei, A. A., Manzoli, V., Fraker, C. A., Giraldo, J., Velluto, D., Najjar, M., et al. (2014). Device design and materials optimization of conformal coating for islets of langerhans. Proceedings of the National Academy of Sciences of the United States of America, 111(29), 10514-10519. https://doi.org/10.1073/pnas. 1402216111.

119. Veiseh, O., Doloff, J. C., Ma, M., Vegas, A. J., Tam, H. H., Bader, A. R., et al. (2015). Size- and shape-dependent foreign body immune response to materials implanted in rodents and non-human primates. Nature Materials, 14(6), 643-651. https://doi.org/10. $1038 /$ nmat4290.

120. Vegas, A. J., Veiseh, O., Doloff, J. C., Ma, M., Tam, H. H., Bratlie, K., et al. (2016). Combinatorial hydrogel library enables identification of materials that mitigate the foreign body response in primates. Nature Biotechnology, 34(3), 345-352. https://doi. org/10.1038/nbt.3462.

121. Vegas, A. J., Veiseh, O., Gürtler, M., Millman, J. R., Pagliuca, F. W., Bader, A. R., et al. (2016). Long-term glycemic control using polymer-encapsulated human stem cell-derived beta cells in immune-competent mice. Nature medicine, 22(3), 306-311. https://doi.org/10.1038/nm.4030.

122. Vaithilingam, V., Bal, S., \& Tuch, B. E. (2017). Encapsulated islet transplantation: where do we stand? The Review of Diabetic Studies, 14(1), 51-78. https://doi.org/10.1900/RDS.2017.14.51.

123. Schweicher, J., Nyitray, C., \& Desai, T. A. (2014). Membranes to achieve immunoprotection of transplanted islets. Frontiers in bioscience (Landmark Ed), 19, 49-76. https://doi.org/10.2741/4195.

124. Hwa, A. J., \& Weir, G. C. (2018). Transplantation of macroencapsulated insulin-producing cells. Current Diabetes Reports, 18(8), 50. https://doi.org/10.1007/s11892-018-1028-y.

125. Rafael, E., Wu, G. S., Hultenby, K., Tibell, A., \& Wernerson, A. (2003). Improved survival of macroencapsulated islets of Langerhans by preimplantation of the immunoisolating device: a morphometric study. Cell Transplantation, 12(4), 407-412. https://doi.org/10.3727/000000003108746957.

126. Sörenby, A. K., Kumagai-Braesch, M., Sharma, A., Hultenby, K. R., Wernerson, A. M., \& Tibell, A. B. (2008). Preimplantation of an immunoprotective device can lower the curative dose of islets to that of free islet transplantation: studies in a rodent model. Transplantation, 86(2), 364-366. https://doi.org/10.1097/TP. 0b013e31817efc78.

127. Fraker, C. A., Cechin, S., Álvarez-Cubela, S., Echeverri, F., Bernal, A., Poo, R., et al. (2013). A physiological pattern of oxygenation using perfluorocarbon-based culture devices maximizes pancreatic islet viability and enhances $\beta$-cell function. Cell Transplantation, 22(9), 1723-1733. https://doi.org/10.3727/ 096368912 X657873.

128. Coronel, M. M., Geusz, R., \& Stabler, C. L. (2017). Mitigating hypoxic stress on pancreatic islets via in situ oxygen generating biomaterial. Biomaterials, 129, 139-151. https://doi.org/10.1016/ j.biomaterials.2017.03.018.

129. Sigrist, S., Mechine-Neuville, A., Mandes, K., Calenda, V., Braun, S., Legeay, G., et al. (2003). Influence of VEGF on the viability of encapsulated pancreatic rat islets after transplantation in diabetic mice. Cell Transplantation, 12(6), 627-635. https:// doi.org/10.3727/000000003108747109.

130. Phelps, E. A., Headen, D. M., Taylor, W. R., Thulé, P. M., \& García, A. J. (2013). Vasculogenic bio-synthetic hydrogel for enhancement of pancreatic islet engraftment and function in type 1 diabetes. Biomaterials, 34(19), 4602-4611. https://doi.org/10. 1016/j.biomaterials.2013.03.012.

131. Weaver, J. D., Headen, D. M., Aquart, J., Johnson, C. T., Shea, L. D., Shirwan, H., et al. (2017). Vasculogenic hydrogel enhances islet survival, engraftment, and function in leading extrahepatic sites. Science Advances, 3(6), e1700184. https://doi.org/10.1126/ sciadv.1700184.

132. Pape, F. L., Cosnuau-Kemmat, L., Richard, G., Dubrana, F., Claude Férec, C., Zal, F., et al. (2017). HEMOXCell, a new oxygen carrier usable as an additive for mesenchymal stem cell culture in platelet lysate-supplemented media. Artificial Organs, 41(4), 359-371. https://doi.org/10.1111/aor.12892.

133. Rodriguez-Brotons, A., Bietiger, W., Peronet, C., Langlois, A., Magisson, J., Mura, C., et al. (2016). Comparison of perfluorodecalin and HEMOXCell as oxygen carriers for islet oxygenation in an in vitro model of encapsulation. Tissue Engineering Part A, 22(23-24), 1-31. https://doi.org/10.1089/ ten.TEA.2016.0064.

134. Sweet, I. R., Yanay, O., Waldron, L., Gilbert, M., Fuller, J. M., Tupling, T., et al. (2009). Treatment of diabetic rats with encapsulated islets. Journal of Cellular and Molecular Medicine, 12(6B), 2644-2650. https://doi.org/10.1111/j.1582-4934.2008. 00322.x.

135. Kumagai-Braesch, M., Jacobson, S., Mori, H., Jia, X., Takahashi, T., Wernerson, A., et al. (2013). The TheraCyte ${ }^{\mathrm{TM}}$ device protects against islet allograft rejection in immunized hosts. Cell Transplantation, 22(7), 1137-1146. https://doi.org/10.3727/ 096368912 X657486.

136. Motté, E., Szepessy, E., Suenens, K., Stangé, G., Bomans, M., Jacobs-Tulleneers-Thevissen, D., et al. (2014). Composition and function of macroencapsulated human embryonic stem cellderived implants: comparison with clinical human islet cell grafts. The American Journal of Physiology-Endocrinology and Metabolism, 307, E838-E846. https://doi.org/10.1152/ajpendo. 00219.2014.

137. Boettler, T., Schneider, D., Cheng, Y., Kadoya, K., Brandon, E. P., Martinson, L., et al. (2016). Pancreatic tissue transplanted in TheraCyte encapsulation devices is protected and prevents hyperglycemia in a mouse model of immune-mediated diabetes. Cell Transplantation, 25(3), 609-614. https://doi.org/10.3727/ $096368915 X 688939$.

138. Gabr, M. M., Zakaria, M. M., Refaie, A. F., Ismail, A. M., Khater, S. M., Ashamallah, S. A., et al. (2018). Insulin-producing cells from adult human bone marrow mesenchymal stromal cells could control chemically induced diabetes in dogs: A preliminary study. Cell Transplantation, 27(6), 937-947. https://doi.org/10.1177/ 0963689718759913.

139. Matveyenko, A. V., Georgia, A., \& Bhushan, A/ \& Butler, P. C. (2010). Inconsistent formation and nonfunction of insulin-positive cells from pancreatic endoderm derived from human embryonic stem cells in athymic nude rats. The American Journal of Physiology-Endocrinology and Metabolism, 299(5), E13-E20. https://doi.org/10.1152/ajpendo.00279.2010.

140. Motté, E., Szepessy, E., Suenens, K., Stangé, G., Bomans, M., Jacobs-Tulleneers-Thevissen, D., et al. (2014). Composition and function of macroencapsulated human embryonic stem cellderived implants: comparison with clinical human islet cell grafts. The American Journal of Physiology-Endocrinology and Metabolism, 307(9), E838-E846. https://doi.org/10.1152/ ajpendo.00219.2014.

141. Odorico, J., Markmann, J., Melton, D., Greenstein, J., Hwa, A., Nostro, C., et al. (2018). Report of the key opinion leaders meeting on stem cell-derived beta cells. Transplantation, 2018, 102(8), 1223-1229. https://doi.org/10.1097/TP.0000000000002217.

142. Pepper, A. R., Pawlick, R., Gala-Lopez, B., MacGillivary, A., Mazzuca, D. M., White, D. J., et al. (2015). Diabetes is reversed 
in a murine model by marginal mass syngeneic islet transplantation using a subcutaneous cell pouch device. Transplantation, 99(11), 2294-2300. https://doi.org/10.1097/TP. 0000000000000864.

143. Gala-Lopez, B. L., Pepper, A. R., Dinyari, P., Malcolm, A. J., Kin, T., Pawlick, L. R., et al. (2016). Subcutaneous clinical islet transplantation in a prevascularized subcutaneous pouch - preliminary experience. Cell R,n,d, 4, e2132.

144. Ludwig, B., Reichel, A., Steffen, A., Zimerman, B., Schally, A. V., Block, N. L., et al. (2013). Transplantation of human islets without immunosuppression. Proceedings of the National Academy of Sciences of the United States of America, 110(47), 19054-19058. https://doi.org/10.1073/pnas.1317561110.

145. Korsgren, O. (2017). Islet Encapsulation: Physiological Possibilities and Limitations. Diabetes, 66(7), 1748-1754. https://doi.org/10.2337/db17-0065.

146. Carlsson, P. O., Espes, D., Sedigh, A., Rotem, A., Zimerman, B., Grinberg, H., et al. (2018). Transplantation of macroencapsulated human islets within the bioartificial pancreas $\beta$ air to patients with type 1 diabetes mellitus. American Journal of Transplantation, 18(7), 1735-1744. https://doi.org/10.1111/ajt.14642.

147. Daoud, J. T., Petropavlovskaia, M. S., Patapas, J. M., Degrandpré, C. E., Diraddo, R. W., Rosenberg, L., et al. (2011). Long-term in vitro human pancreatic islet culture using three-dimensional microfabricated scaffolds. Biomaterials, 32(6), 1536-1542. https://doi.org/10.1016/j.biomaterials.2010.10.036.

148. Khorsandi, L., Khodadadi, A., Nejad-Dehbashi, F., \& Saremy, S. (2015). Three-dimensional differentiation of adipose-derived mesenchymal stem cells into insulin-producing cells. Cell and Tissue Research, 361(3), 745-753. https://doi.org/10.1007/s00441-0152140-9.

149. Kasputis, T., Clough, D., Noto, F., Rychel, K., Dye, B., \& Shea, L. D. (2018). Microporous polymer scaffolds for the transplantation of embryonic stem cell derived pancreatic progenitors to a clinically translatable site for the treatment of type I diabetes. ACS Biomaterials Science \& Engineering, 4(5), 1770-1778. https:// doi.org/10.1021/acsbiomaterials.7b00912.

150. Ojaghi, M., Soleimanifar, F., Kazemi, A., Ghollasi, M., Soleimani, M., Nasoohi, N., et al. (2019). Electrospun poly-l-lactic acid/ polyvinyl alcohol nanofibers improved insulin-producing cell differentiation potential of human adipose-derived mesenchymal stem cells. Journal of Cellular Biochemistry, 120(6), 99179926. https://doi.org/10.1002/jcb.28274.

151. Gharravi, A. M., Jafar, A., Ebrahimi, M., Mahmodi, A., Pourhashemi, E., Haseli, N., et al. (2018). Current status of stem cell therapy, scaffolds for the treatment of diabetes mellitus. Diabetes, Metabolic Syndrome, 12(6), 1133-1139. https://doi. org/10.1016/j.dsx.2018.06.021.

152. Kumar, N., Joisher, H., \& Ganguly, A. (2018). Polymeric scaffolds for pancreatic tissue engineering: a review. Review of Diabetic Studies, 14(4), 334-353. https://doi.org/10.1900/RDS. 2017.14.334.

153. Hall Barrientos, I. J., MacKenzie, G. R., Wilson, C. G., Lamprou, D. A., \& Coats, P. (2019). Biological performance of electrospun polymer fibres. Materials (Basel), 12(3), 363. https://doi.org/10. 3390/ma12030363.

154. Mitrousis, N., Fokina, A., \& Shoichet, M. S. (2018). Biomaterials for cell transplantation. Nature Reviews Materials, 3, 441-456.

155. Salvay, D. M., Rives, C. B., Zhang, X., Chen, F., Kaufman, D. B., Lowe Jr., W. L., et al. (2008). Extracellular matrix protein-coated scaffolds promote the reversal of diabetes after extrahepatic islet transplantation. Transplantation, 85(10), 1456-1464. https://doi. org/10.1097/TP.0b013e31816fc0ea.

156. Yap, W. T., Salvay, D. M., Silliman, M. A., Zhang, X., Bannon, Z. G., Kaufman, D. B., et al. (2013). Collagen IV-modified scaffolds improve islet survival and function and reduce time to euglycemia.
Tissue Engineering Part A, 19(21-22), 2361-2372. https://doi.org/ 10.1089/ten.TEA.2013.0033.

157. Vernon, R. B., Preisinger, A., Gooden, M. D., D'Amico, L. A., Yue, B. B., Bollyky, P. L., et al. (2012). Reversal of diabetes in mice with a bioengineered islet implant incorporating a type $\mathrm{i}$ collagen hydrogel and sustained release of vascular endothelial growth factor. Cell Transplantation, 21(10), 2099-2110. https:// doi.org/10.3727/096368912X636786.

158. Asawa, Y., Sakamoto, T., Komura, M., Watanabe, M., Nishizawa, S., Takazawa, Y., et al. (2012). Early stage foreign body reaction against biodegradable polymer scaffolds affects tissue regeneration during the autologous transplantation of tissue-engineered cartilage in the canine model. Cell Transplantation, 21(7), 1431-1442. https://doi.org/10.3727/096368912X640574.

159. Goh, S. K, Bertera, S., Olsen, P., Candiello, J. E., Halfter, W., Uechi, G., et al. (2013). Perfusion-decellularized pancreas as a natural $3 \mathrm{~d}$ scaffold for pancreatic tissue and whole organ engineering. Biomaterials, 34(28), 6760-6772. https://doi.org/10.1016/j. biomaterials.2013.05.066

160. Matlaga, B. F., Yasenchak, L. P., \& Salthouse, T. N. (1976). Tissue response to implanted polymers: the significance of sample shape. Journal of Biomedical Materials Research, 10(3), 391397. https://doi.org/10.1002/jbm.820100308.

161. Smink, A. M., Li, S., Hertsig, D. T., de Haan, B. J., Leendert Schwab, L., van Apeldoorn, A. A., de Koning, E., et al. (2017). The efficacy of a prevascularized, retrievable poly(d,1,-lactide-co$\varepsilon$-caprolactone) subcutaneous scaffold as transplantation site for pancreatic islets. Transplantation, 101(4), e112-e119. https://doi. org/10.1097/TP.0000000000001663

162. Pedraza, E., Brady, A. C., Fraker, C. A., Molano, R. D., Sukert, S., Berman, D. M., et al. (2013). Macroporous Three-dimensional PDMS scaffolds for extrahepatic islet transplantation. Cell Transplantation, 22(7), 1123-1135. https://doi.org/10.3727/ 096368912 X657440.

163. Rasmusson, I. (2006). Immune modulation by mesenchymal stem cells. Experimental Cell Research, 312(12), 2169-2179. https:// doi.org/10.1016/j.yexcr.2006.03.019.

164. Jacobs, S. A., Pinxteren, J., Roobrouck, V. D., Luyckx, A., van't Hof, W., Deans, R., et al. (2013). Human multipotent adult progenitor cells are nonimmunogenic and exert potent immunomodulatory effects on alloreactive T-cell responses. Cell Transplantation, 22(10), 1915-1928. https://doi.org/10.3727/ 096368912 X657369.

165. Le Blanc, K., \& Davies, L. C. (2015). Mesenchymal stromal cells and the innate immune response Immunology Letters, 168(2), 140146. https://doi.org/10.1016/j.imlet.2015.05.004

166. Tse, W. T., Pendleton, J. D., Beyer, W. M., Egalka, M. C., \& Guinan, E. C. (2003). Suppression of allogeneic T-cell proliferation by human marrow stromal cells: implications in transplantation. Transplantation, 75(3), 389-397. https://doi.org/10.1097/01. TP.0000045055.63901.A9.

167. Augello, A., Tasso, R., Negrini, S. M., Amateis, A., Indiveri, F., Cancedda, R., et al. (2005). Bone marrow mesenchymal progenitor cells inhibit lymphocyte proliferation by activation of the programmed death 1 pathway. European Journal of Immunology, 35(5), 1482-1490. https://doi.org/10.1002/eji.200425405.

168. Ma, O. K., \& Chan, K. H. (2016). Immunomodulation by mesenchymal stem cells: Interplay between mesenchymal stem cells and regulatory lymphocytes. World Journal of Stem Cells, 8(9), 268278. https://doi.org/10.4252/wjsc.v8.i9.268.

169. Shi, Y., Wang, Y., Li, Q., Liu, K., Hou, J., Shao, C., et al. (2018). Immunoregulatory mechanisms of mesenchymal stem and stromal cells in inflammatory diseases. Nature Reviews Nephrology, 14(8), 493-507. https://doi.org/10.1038/s41581-018-0023-5.

170. Weiss, A. R., \& Dahlke, M. H. (2019). Immunomodulation by Mesenchymal Stem Cells (MSCs): Mechanisms of action of 
Living, Apoptotic, and Dead MSCs. Frontiers in immunology, 10, 1191. https://doi.org/10.3389/fimmu.2019.01191.

171. Bartholomew, A., Sturgeon, C., Siatskas, M., Ferrer, K., Mclntosh, K., Patil, S., et al. (2002). Mesenchymal stem cells suppress lymphocyte proliferation in vitro and prolong skin graft survival in vivo. Experimental Hematology, 30(1), 42-48. https:// doi.org/10.1016/s0301-472x(01)00769-x.

172. Shi, M., Liu, Z. W., \& Wang, F. S. (2011). Immunomodulatory properties and therapeutic application of mesenchymal stem cells. Clinical \& Experimental Immunology, 164(1), 1-8. https://doi. org/10.1111/j.1365-2249.2011.04327.x.

173. Zhao, Q., Ren, H., \& Han, Z. (2016). Mesenchymal stem cells: Immunomodulatory capability and clinical potential in immune diseases. Journal of Cellular Immunotherapy, 2(1), 3-20. https:// doi.org/10.1016/j.jocit.2014.12.001.

174. Gao, F., Chiu, S. M., Motan, D. A., Zhang, Z., Chen, L., Ji, H. L., et al. (2016). Mesenchymal stem cells and immunomodulation: Current status and future prospects. Cell Death \& Disease, 7(1), e2062. https://doi.org/10.1038/cddis.2015.327.

175. Lee, R. H., Seo, M. J., Reger, R. L., Spees, J. L., Pulin, A. A., Olson, S. D., et al. (2006). Multipotent stromal cells from human marrow home to and promote repair of pancreatic islets and renal glomeruli in diabetic NOD/scid mice. Proceedings of the National Academy of Sciences of the United States of America, 103(46), 17438-17443. https://doi.org/10.1073/pnas.0608249103.

176. Madec, A. M., Mallone, R., Afonso, G., Abou Mrad, E., Mesnier, A., Eljaafari, A., \& al. (2009). Mesenchymal stem cells protect NOD Mice from diabetes by inducing regulatory $\mathrm{T}$ cell. Diabetologia, 52(7), 1391-1399. https://doi.org/10.1007/s00125009-1374-Z

177. Yang, X. F., Che, T., Ren, L. W., Yang, L., Qi, H., \& Li, F. R. (2017). Immunogenicity of insulin-producing cells derived from human umbilical cord mesenchymal stem cells. Experimental and Therapeutic Medicine, 13(4), 1456-1464. https://doi.org/10.3892/ etm.2017.4096

178. Poncelet, A. J., Vercruysse, J., Saliez, A., \& Gianello, P. (2007). Although pig allogeneic mesenchymal stem cells are not immunogenic in vitro, intracardiac injection elicits an immune response in vivo. Transplantation, 83(6), 783-790. https://doi.org/10.1097/ 01.tp.0000258649.23081.a3.

179. Lohan, P., Coleman, C. M., Murphy, J. M., Griffin, M. D., Ritter, T., \& Ryan, A. E. (2014). Changes in immunological profile of allogeneic mesenchymal stem cells after differentiation: should be concerned? Stem Cell Research \& Therapy, 5(4), 99. https://doi. org/10.1186/scrt488.

180. Valencia, J., Blanco, B., Yáñez, R., Vázquez, M., Sánchez, C. H., Fernández-García, M., et al. (2016). Comparative analysis of the immunomodulatory capacities of human bone marrow-and adipose tissue-derived mesenchymal stromal cells from the same donor. Cytotherapy, 18(10), 1297-1311. https://doi.org/10.1016/j. jcyt.2016.07.006.
181. Gu, L. H., Zhang, T. T., Li, Y., Yan, H. J., Qi, H., \& Li, F. R. (2015). Immunogenicity of allogeneic mesenchymal stem cells transplanted via different routes in diabetic rats. Cellular \& Molecular Immunology, 12(4), 444-455. https://doi.org/10.1038/ cmi.2014.70.

182. Nauta, A. J., Westerhuis, G., Kruisselbrink, A. B., Lurvink, E. G., \& Willemze, R.,\& Fibbe, W. E. (2006). Donor-derived mesenchymal stem cells are immunogenic in an allogeneic host and stimulate donor graft rejection in a nonmyeloablative setting. Blood, 108(6), 2114-2120. https://doi.org/10.1182/blood-2005-11011650.

183. Technau, A., Froelich, K., Hagen, R., \& Kleinsasser, N. (2011). Adipose tissue-derived stem show both immunogenic and immunosuppressive properties after chondrogenic differentiation. Cytotherapy, 13(3), 310-317. https://doi.org/10.3109/14653249. 2010.504769.

184. Berglund, A. K., Fortier, L. A., Antczak, D. F., \& Schnabel, L. V. (2017). Immunoprivileged no more: measuring the immunogenicity of allogeneic adult mesenchymal stem cells. Stem Cell Research \& Therapy, 8(1), 288. https://doi.org/10.1186/s13287017-0742-8.

185. del Rio, M. L., Buhler, L., Gibbons, C., Tian, J., \& RodriguezBarbosa, J. I. (2008). PD-1/PD-L 1 , PD-1/PD-L 2 , and other coinhibitory signaling pathways in transplantation. Transplant International, 21(11), 1015-1028. https://doi.org/10.1111/j. 1432-2277.2008.00726.x.

186. Davies, L. C., Heldring, N., Kadri, N., \& Le Blanc, K. (2017). Mesenchymal stromal cell secretion of programmed death-1 ligands regulates T cell mediated immunosuppression. Stem Cells, 35(3), 766-776. https://doi.org/10.1002/stem.2509.

187. Salama, A. D., Chitnis, T., Imitola, J., Ansari, M. J., Akiba, H., Tushima, F., et al. (2003). Critical role of the programmed death-1 ( PD-1 ) pathway in regulation of experimental autoimmune encephalomyelitis. Journal of Experimental Medicine, 198(1), 7178. https://doi.org/10.1084/jem.20022119

188. Lauden, L., Boukouaci, W., Borlado, L. R., López, I. P., Sepúlveda, P., Tamouza, R., et al. (2013). Allogenicity of human cardiac stem/progenitor cells orchestrated by programmed death ligand 1. Circulation Research, 112(3), 451-464. https://doi.org/ 10.1161/CIRCRESAHA.112.276501.

189. Al-Daccak, R., \& Charron, D. (2015). Allogenic benefit in stem cell therapy: cardiac repair and regeneration. Tissue Antigens, 86(3), 155-162. https://doi.org/10.1111/tan.12614.

190. Hocine, H. R., Costa, H. E., Dam, N., Giustiniani, J., Palacios, I., Loiseau, P., et al. (2017). Minimizing the risk of allo-sensitization to optimize the benefit of allogeneic cardiac-derived stem/ progenitor cells. Scientific Reports, 7, 41125. https://doi.org/10. 1038/srep411.

Publisher's Note Springer Nature remains neutral with regard to jurisdictional claims in published maps and institutional affiliations. 